\title{
A Systematic Re-evaluation of Methods for Quantification of Bulk Particle-phase Organic Nitrates Using Real-time Aerosol Mass Spectrometry
}

\author{
Douglas A. Day, ${ }^{1,2}$ Pedro Campuzano-Jost, ${ }^{1,2}$ Benjamin A. Nault, ${ }^{1,2, a}$ Brett B. Palm, ${ }^{1,2, b}$ Weiwei Hu, ${ }^{1,2, c}$ \\ 5 Hongyu Guo, ${ }^{1,2}$ Paul J. Wooldridge, ${ }^{3}$ Ronald C. Cohen, ${ }^{3,4}$ Kenneth. S. Docherty, ${ }^{5}$ J. Alex Huffman, ${ }^{6}$ \\ Suzane S. de Sá, ${ }^{7}$ Scot T. Martin, ${ }^{7,8}$ Jose L. Jimenez ${ }^{1,2}$ \\ ${ }^{1}$ Cooperative Institute for Research in Environmental Sciences, University of Colorado, Boulder, CO, USA \\ ${ }^{2}$ Dept. of Chemistry, University of Colorado, Boulder, CO, USA \\ ${ }^{3}$ Department of Chemistry, University of California Berkeley, Berkeley, CA, USA \\ $10{ }^{4}$ Department of Earth and Planetary Science, University of California Berkeley, Berkeley, CA, USA \\ ${ }_{5}^{5}$ Jacobs Technology, Inc., Research Triangle Park, NC, USA \\ ${ }^{6}$ Department of Chemistry and Biochemistry, University of Denver, Denver, CO USA \\ ${ }^{7}$ School of Engineering and Applied Sciences, Harvard University, Cambridge, Massachusetts, USA \\ ${ }^{8}$ Department of Earth and Planetary Sciences, Harvard University, Cambridge, Massachusetts, USA \\ 15 anow at: Center for Aerosol and Cloud Chemistry, Aerodyne Research Inc., Billerica, MA, USA \\ bnow at: Atmospheric Chemistry Observations and Modeling Laboratory, National Center for Atmospheric Research, Boulder, CO, USA \\ 'now at: State Key Laboratory at Organic Geochemistry, Guangzhou Institute of Geochemistry, Chinese Academy of Sciences, Guangzhou, China
}

Correspondence: Douglas A. Day (douglas.day@colorado.edu) and Jose L. Jimenez (jose.jimenez@colorado.edu)

\section{Abstract}

20 Organic nitrate $\left(\mathrm{RONO}_{2}\right)$ formation in the atmosphere represents a sink of $\mathrm{NO}_{\mathrm{x}}\left(\mathrm{NO}_{\mathrm{x}}=\mathrm{NO}+\mathrm{NO}_{2}\right)$ and termination of the $\mathrm{NO}_{x} / \mathrm{HO}_{x}\left(\mathrm{HO}_{x}=\mathrm{HO}_{2}+\mathrm{OH}\right)$ ozone formation and radical propagation cycles, can act as a $\mathrm{NO}_{\mathrm{x}}$ reservoir transporting reactive nitrogen, and contributes to secondary organic aerosol formation. While some fraction of $\mathrm{RONO}_{2}$ is thought to reside in the particle phase, particle-phase organic nitrates $\left(\mathrm{pRONO}_{2}\right)$ are infrequently measured and thus poorly understood. There is an increasing prevalence of

25 aerosol mass spectrometer (AMS) instruments, which have shown promise for determining quantitative total organic nitrate functional group contribution to aerosols. A simple approach that relies on the relative intensities of $\mathrm{NO}^{+}$and $\mathrm{NO}_{2}{ }^{+}$ions in the AMS spectrum, the calibrated $\mathrm{NO}_{\mathrm{x}}^{+}$ratio for $\mathrm{NH}_{4} \mathrm{NO}_{3}$, and the inferred ratio for $\mathrm{pRONO}_{2}$ has been proposed as a way to apportion the total nitrate signal to $\mathrm{NH}_{4} \mathrm{NO}_{3}$ and $\mathrm{pRONO}_{2}$. This method is increasingly being applied to field and laboratory data. However,

30 the methods applied have been largely inconsistent and poorly characterized, and therefore, a detailed evaluation is timely. Here, we compile an extensive survey of $\mathrm{NO}_{\mathrm{x}}{ }^{+}$ratios measured for various $\mathrm{pRONO}_{2}$ compounds and mixtures from multiple AMS instruments, groups, and laboratory and field measurements. We show that, in the absence of $\mathrm{pRONO}_{2}$ standards, the $\mathrm{pRONO}_{2} \mathrm{NO}_{\mathrm{x}}^{+}$ratio can be estimated using a ratio referenced to the calibrated $\mathrm{NH}_{4} \mathrm{NO}_{3}$ ratio, a so-called "Ratio-of-Ratios" method

$35(R o R=2.75 \pm 0.41)$. We systematically explore the basis for quantifying $\mathrm{pRONO} \mathrm{N}_{2}\left(\right.$ and $\left.\mathrm{NH}_{4} \mathrm{NO}_{3}\right)$ with the $R o R$ method using ground and aircraft field measurements conducted over a large range of conditions. The method is compared to another AMS method (positive matrix factorization, PMF) and other $\mathrm{pRONO}_{2}$ and related (e.g., total gas + particle $\mathrm{RONO}_{2}$ ) measurements, generally showing good agreement / correlation. A broad survey of ground and aircraft AMS measurements shows a pervasive trend of higher

40 fractional contribution of $\mathrm{pRONO}_{2}$ to total nitrate with lower total nitrate concentrations, which generally corresponds to shifts from urban-influenced to rural/remote regions. Compared to ground campaigns, observations from all aircraft campaigns showed substantially lower $\mathrm{pRONO}_{2}$ contributions at mid ranges of total nitrate (0.01-0.1 up to 2-5 $\mu \mathrm{g} \mathrm{m}^{-3}$ ), suggesting that the balance of effects controlling $\mathrm{NH}_{4} \mathrm{NO}_{3}$ and $\mathrm{pRONO}_{2}$ formation and lifetimes - such as higher humidity, lower temperatures, greater dilution, different sources, higher particle acidity, and $\mathrm{pRONO}_{2}$ hydrolysis (possibly accelerated by particle acidity) - favors lower $\mathrm{pRONO}_{2}$ contributions for those environments and altitudes sampled. 


\section{Introduction}

Organic nitrate $\left(\mathrm{RONO}_{2}\right)$ formation in the atmosphere, through oxidation of VOCs (volatile organic compounds) in the presence of $\mathrm{NO}_{\mathrm{x}}\left(\mathrm{NO}_{\mathrm{x}}=\mathrm{NO}+\mathrm{NO}_{2}\right)$, represents a sink of $\mathrm{NO}_{\mathrm{x}}$ and termination of the catalytic $\mathrm{NO}_{\mathrm{x}} / \mathrm{HO}_{\mathrm{x}}\left(\mathrm{HO}_{\mathrm{x}}=\mathrm{OH}+\mathrm{HO}_{2}\right)$ ozone formation and radical propagation cycles, can act as a $\mathrm{NO}_{\mathrm{x}}$ reservoir transporting (or removing) reactive nitrogen, and contribute to secondary organic aerosol formation (Zare et al., 2018 and references therein). Particle-phase organic nitrates $\left(\mathrm{pRONO}_{2}\right)$ have been shown to contribute substantial mass to organic aerosol (OA) (Ng et al., 2017 and references therein), can provide insight into the chemistry controlling SOA formation (e.g., Pye et al., 2015; Xu et al., 2015b; Lee 55 et al., 2016; Ng et al., 2017), may constitute a semivolatile component of OA and dynamically partition between the gas- and particle-phases (e.g., Fry et al., 2013; Rollins et al., 2013; Pye et al., 2015), and represent a loss mechanism for $\mathrm{RONO}_{2}$ or reactive nitrogen oxides (e.g., via hydrolysis or deposition) (Fisher et al., 2016; Lee et al., 2016; Zare et al., 2018). However, $\mathrm{pRONO}_{2}$ have infrequently been measured in ambient air until recently and thus are still poorly understood ( $\mathrm{Ng}$ et al., 2017).

60 The recent emergence of a variety of online and offline methods of both speciated and bulk $\mathrm{pRONO}_{2}$ and their applications to ambient aerosol measurements are summarized in $\mathrm{Ng}$ et al. (2017). Instrumentation and methods include: (online bulk) aerosol mass spectrometry (AMS; (Jayne et al., 2000)) and its monitoring versions (known as Aerosol Chemical Speciation Monitors, ACSM; (Ng et al., 2011; Fröhlich et al., 2013)); thermal dissociation - laser induced fluorescence (TD-LIF; (Day et al.,

65 2002)); (online speciated) filter inlet for gases and aerosols (FIGAERO) - chemical ionization mass spectrometry (CIMS) (Lopez-Hilfiker et al., 2014); (offline speciated) high-pressure liquid chromatography - mass spectrometry (HPLC/MS) often with electrospray ionization (ESI) (Surratt et al., 2006); (offline bulk) Fourier Transform InfraRed (FTIR) spectroscopy (Maria et al., 2002). While speciated methods can provide more detailed source or mechanistic information, they are slow and, to

70 date, none (online nor offline) has demonstrated quantitative measurement of the bulk of $\mathrm{pRONO}_{2}$ for ambient measurements. Therefore, bulk measurements provide useful constraints on the budgets, formation and loss rates of gas- and aerosol-phase $\mathrm{RONO}_{2}$ in the atmosphere; and fast online methods are essential when ambient concentrations are rapidly changing, especially for aircraft sampling.

For most field applications of the AMS, typically aerosol nitrate concentrations have been reported as

75 a single total (organic plus inorganic) concentration, due to the fact that nearly all of the signal of the nitrate functional group for any nitrate type (or nitrite) is measured at a couple of common ion peaks $\left(\mathrm{NO}^{+}\right.$and $\mathrm{NO}_{2}{ }^{+}$in high-resolution (HR) instruments or $\mathrm{m} / \mathrm{z} 30$ and $\mathrm{m} / \mathrm{z} 46$ in unit mass resolution (UMR) instruments) (Farmer et al., 2010). Early on in the application of the AMS, an implicit assumption was often made that ammonium nitrate $\left(\mathrm{NH}_{4} \mathrm{NO}_{3}\right)$ typically dominated aerosol nitrate, based on early urban

80 studies that showed semivolatile behavior consistent with $\mathrm{NH}_{4} \mathrm{NO}_{3}$ (e.g., Jimenez et al., 2003; Hogrefe et al., 2004; Zhang et al., 2004). However, a few early reports on field measurements using UMR AMS (Allan et al., 2004b, 2006) showed that the $m / z 46$ - to - $m / z 30$ ratio (hereinafter " $46 / 30$ ratio") was too low to be associated with only $\mathrm{NH}_{4} \mathrm{NO}_{3}$, suggesting substantial contributions from mineral nitrates $\left(\mathrm{NaNO}_{3}, \mathrm{Ca}\left(\mathrm{NO}_{3}\right)_{2}\right), \mathrm{pRONO}_{2}$, or possibly other reduced organo-nitrogen, or organic ion interferences. In 85 a study focusing on cluster analysis of ambient (UMR) AMS spectra, Marcolli et al. (2006) also reported 46/30 ratios substantially smaller than $\mathrm{NH}_{4} \mathrm{NO}_{3}$ and found several spectra cluster categories with dominant $\mathrm{m} / \mathrm{z} 30$ peaks (but not $\mathrm{m} / \mathrm{z} 46$ ) and suggested that these signals may be associated with organic 
nitrates. Similarly, Alfarra et al. (2006) reported 46/30 ratios from chamber-generated SOA (photooxidation of trimethyl benzene and $\alpha$-pinene) $\sim 2-4$ times lower than $\mathrm{NH}_{4} \mathrm{NO}_{3}$, which they attributed to $\mathrm{pRONO}_{2}$ or nitro-compounds. A few years later, reports from chamber studies where pRONO 2 -rich SOA was generated ( $\beta$-pinene or isoprene $+\mathrm{NO}_{3}$ radicals), using an HR-AMS, showed $\mathrm{NO}_{2}^{+} / \mathrm{NO}^{+}$ratios (hereafter " $\mathrm{NO}_{\mathrm{x}}^{+}$ratio") $\sim 2-4$ times lower than pure $\mathrm{NH}_{4} \mathrm{NO}_{3}$ (Fry et al., 2009; Rollins et al., 2009).

Subsequently, broader surveys of the fragmentation patterns of aerosol nitrates (and nitrites) in the

95 AMS were reported, including consistently low $\mathrm{NO}_{\mathrm{x}}^{+}$ratios for $\mathrm{pRONO}_{2}$ (Bruns et al., 2010; Farmer et al., 2010). Farmer et al. (2010) evaluated the fragmentation patterns of single-component $\mathrm{pRONO}_{2}$ isolated from $\mathrm{SOA}$, and showed that $\sim 95 \%$ the nitrogen-containing signal was observed as $\mathrm{NO}_{\mathrm{x}}^{+}$ions with the balance as $\mathrm{HNO}_{3}{ }^{+}$and very little signal at $\mathrm{C}_{\mathrm{x}} \mathrm{H}_{\mathrm{y}} \mathrm{O}_{\mathrm{z}} \mathrm{N}^{+}$ions. Farmer et al. evaluated several methods for constraining $\mathrm{pRONO}_{2}$ contribution to AMS nitrate signal including using: 1) $\mathrm{NO}_{\mathrm{x}}^{+}$ratios, 2) $\mathrm{HNO}_{3}^{+}$ions,

100 3) $\mathrm{C}_{x} \mathrm{H}_{y} \mathrm{O}_{z} \mathrm{~N}^{+}$ions, 4) "ammonium balance", and 5) AMS total nitrate comparison to inorganic nitrate-only measured with another instrument (typically ion chromatography-based). For the urban dataset evaluated in that study, all methods appeared to be associated with relatively large uncertainties. Bruns et al. (2010) reported $\mathrm{NO}_{\mathrm{x}}^{+}$ratios for SOA formed from several monoterpenes and isoprene (with $\mathrm{NO}_{3}$ radicals) as well as $\mathrm{NaNO}_{3}$ and $\mathrm{NaNO}_{2}$ (with the sodium salts showing greatly reduced $\mathrm{NO}_{x}^{+}$ratios). Other studies have

105 used the ammonium balance (hereafter $\mathrm{NH}_{4-3 a l}$ ) of AMS data, or comparisons to other instruments to estimate pRONO ${ }_{2}$ content (Aiken et al., 2009; Zaveri et al., 2010; Docherty et al., 2011; Häkkinen et al., 2012; Xu et al., 2015a); however, in most cases, uncertainties were large or not assessed. Since the Farmer et al. study, several other laboratory studies reported $\mathrm{NO}_{\mathrm{x}}^{+}$ratios for $\mathrm{pRONO}_{2}$-containing $\mathrm{SOA}$, which are summarized in Sect. 3. Additionally, a number of analyses of field studies have used the $\mathrm{NO}_{\mathrm{x}}^{+}$

110 ratios (or its 46/30 UMR equivalent) to support qualitative or semi-quantitative statements about the presence (or low contribution) of pRONO 2 (Setyan et al., 2012; Brown et al., 2013; Xu et al., 2016; Schneider et al., 2017; Bottenus et al., 2018) or to quantify pRONO ${ }_{2}$ (Fry et al., 2013, 2018; Ayres et al., 2015; Kostenidou et al., 2015; Xu et al., 2015a, 2021; Fisher et al., 2016; Kiendler-Scharr et al., 2016; Lee et al., 2016, 2019; Nault et al., 2016; Zhou et al., 2016; Zhu et al., 2016, 2021; Florou et al., 2017;

115 Palm et al., 2017; Brito et al., 2018; de Sá et al., 2018, 2019; Reyes-Villegas et al., 2018; Schulz et al., 2018; Avery et al., 2019; Dai et al., 2019; Huang et al., 2019a, 2019b; Yu et al., 2019; Chen et al., 2020, 2021). Yu et al. (2019) also used the particle size dependence of the $46 / 30$ ratio to investigate particle size and temporal (diurnal and seasonal) trends in $\mathrm{pRONO}_{2}$. Other studies have used positive matrix factorization (PMF) of AMS spectra including both the $\mathrm{OA}$ and $\mathrm{NO}_{\mathrm{x}}^{+}$signals to quantify $\mathrm{pRONO}_{2}$ (Sun et

120 al., 2012; Hao et al., 2014; Xu et al., 2015a; Zhang et al., 2016; Kortelainen et al., 2017; Yu et al., 2019; Zhu et al., 2021). Recently, Xu et al., (2021) demonstrated another method, using AMS thermal denuder measurements. Thus there is promising use of AMS measurements for quantifying bulk $\mathrm{pRONO}_{2}$ functional group contribution to ambient aerosols (and in addition, providing higher quality $\mathrm{NH}_{4} \mathrm{NO}_{3}$ concentrations). However, the methods have not been standardized and uncertainties of the different

125 methods have not been well-characterized, and were reported to be large by at least some studies. Together with the increasing prevalence of AMS (and ACSM) field measurements, a detailed evaluation of $\mathrm{pRONO}_{2}$ quantification methods is timely. Here we explore the application of the $\mathrm{AMS} \mathrm{NO}_{\mathrm{x}}^{+}$ratio method to separate and quantify inorganic and organic nitrate and discuss the methods in detail, as well as comparison to other methods, and some scientific applications. In addition to drawing from available 
130 literature whenever possible, new analyses for several field and laboratory datasets are used extensively throughout this manuscript to explore and support findings. Descriptions of those datasets and data processing methods can be found in Supp. Info. Sect. S1 (including Fig. S1).

\section{Previous use and methods for $\mathrm{pRONO}_{2}$ quantification using $\mathrm{AMS} \mathrm{NO}_{\mathrm{x}}^{+}$ratios}

An equation for quantitative apportionment of the AMS nitrate signal into $\mathrm{pRONO}_{2}$ and $\mathrm{NH}_{4} \mathrm{NO}_{3}$ using

135 the $\mathrm{NO}_{\mathrm{x}}^{+}$ratio was first presented by Farmer et al. (2010) (equation 1 from Farmer et al., and derived in their supporting information, here substituting different notation for some terms for consistency with this manuscript):

$$
f_{\text {pRONO}_{2}}=\frac{\left(R_{\text {ambient }}-R_{\mathrm{NH}_{4} \mathrm{NO}_{3}}\right)\left(1+R_{\text {pRONO}}\right)}{\left(R_{p R O N O}-R_{\mathrm{NH}_{4} \mathrm{NO}_{3}}\right)\left(1+R_{\text {ambient }}\right)}
$$

where $f_{\mathrm{pRONO} 2}$ is the fraction of total AMS nitrate (hereafter $\mathrm{pNO}_{3}$ ) that is $\mathrm{pRONO}_{2}$, and $R_{\mathrm{NH} 4 \mathrm{NO} 3}, R_{\mathrm{pRONO} 2}$, and $R_{\text {ambient }}$ are the $\mathrm{NO}_{\mathrm{x}}{ }^{+}$ratios $\left(\mathrm{NO}_{2}{ }^{+} / \mathrm{NO}^{+}\right)$for pure $\mathrm{NH}_{4} \mathrm{NO}_{3}$, pure $\mathrm{pRONO}$, and the ambient aerosol nitrate mixture measured, respectively. Note that here we use the $\mathrm{NO}_{2}^{+} / \mathrm{NO}^{+}$ratio for all terms, while Farmer et al. and some others have used $\mathrm{NO}^{+} / \mathrm{NO}_{2}{ }^{+}$. This formulation is preferred since $\mathrm{NO}_{2}{ }^{+}$tends to be lower than $\mathrm{NO}^{+}$for all nitrates, and thus using $\mathrm{NO}_{2}^{+} / \mathrm{NO}^{+}$avoids ratios trending toward infinity as detection limits are approached. This usage has been applied in several publications, such as Fry et al.

145 (2013) and Kiendler-Scharr et al. (2016), as presented in equations 11 and 1 in those papers, respectively. The equation is identical regardless of the inversion of the $\mathrm{NO}_{x}^{+}$ratio. That can be shown by simply swapping all the instances of $\mathrm{NO}$ and $\mathrm{NO}_{2}$ in the definitions and derivation shown in Farmer et al. or by substituting $1 / \mathrm{R}_{\mathrm{x}}$ for each ratio term in Eq. 1 above, multiplying all parenthetical terms by $R_{\text {ambient }} R_{\mathrm{NH} 4 \mathrm{NO} 3} R_{\mathrm{pRONO} 2}$, factoring out the same term in the numerator and denominator then canceling, and 150 finally multiplying the first parenthetical terms in the numerator and denominator by -1 . While typically $R_{\mathrm{NH} 4 \mathrm{NO} 3}$ is measured frequently as pure $\mathrm{NH}_{4} \mathrm{NO}_{3}$ is periodically sampled by the AMS as a primary calibrant for sensitivity (Canagaratna et al., 2007), regular calibration using $\mathrm{pRONO}_{2}$ is generally not practical. Moreover, it is not immediately clear that all $\mathrm{pRONO}_{2}$ produce the same $R_{\mathrm{pRONO} 2}$ in the AMS. Values reported in the literature for $R_{\mathrm{NH} 4 \mathrm{NO} 3}$ and $R_{\mathrm{pRONO} 2}$ both appear to have a substantial range (factor of $155 \sim 3$ ) and generally $R_{\mathrm{pRONO} 2}$ is $2-4$ times lower than $R_{\mathrm{NH} 4 \mathrm{NO} 3}$ (see Sects. 1 and 3).

Several studies have applied Eq. 1 to quantify $\mathrm{pRONO}_{2}$ and $\mathrm{NH}_{4} \mathrm{NO}_{3}$, using different assumptions regarding $R_{\mathrm{pRONO} 2}$. Farmer et al. (2010) applied their measurements of $R_{\mathrm{pRONO} 2}$ from their lab study to estimate an upper limit of $50 \%$ for the $\mathrm{pRONO}_{2}$ contribution to $\mathrm{pNO}_{3}$ for the urban SOAR campaign, substantially higher than with other methods they applied. They considered that method to be a high

160 upper limit, due to the possible influence of non-refractory nitrates. However, we note that the $R_{\mathrm{pRONO} 2}$ used in that early study was nearly a factor of two different than we suggest in this study, in the direction favorable to higher $\mathrm{pRONO}_{2}$ fractions. For calculation of $\mathrm{pRONO}_{2}$ for the BEACHON-RoMBAS campaign, Fry et al. (2013) assert that $R_{\mathrm{NH} 4 \mathrm{NO} 3}$ and $R_{\mathrm{pRONO} 2}$ likely co-vary for an instrument and therefore define the term "ratio-of-ratios" (hereafter $R o R=R_{\mathrm{NH} 4 \mathrm{NO} 3} / R_{\mathrm{pRONO} 2}$ ) in order to estimate $R_{\mathrm{pRONO} 2}$ from

165 in-field $R_{\mathrm{NH} 4 \mathrm{NO} 3}$ measurements and literature reports of $R_{\mathrm{pRONO} 2}$ and $R_{\mathrm{NH} 4 \mathrm{NO} 3}$. The RoR value applied by Fry et al. (2013) was 2.25, based on the Farmer et al. (2010) average. On the other hand, in an analysis of pRONO 2 contribution to OA throughout Europe, Kiendler-Scharr et al. (2016) applied a fixed $R_{\mathrm{pRONO} 2}$ of 0.1 based on literature reports of $R_{\mathrm{pRONO} 2}$, and the argument that it was the minimum ratio observed in the ambient datasets examined (noting that "such low ratios of $\mathrm{NO}_{2}^{+} / \mathrm{NO}^{+}$were also detected in some data 
170 sets where $R_{\mathrm{NH} 4 \mathrm{NO} 3}$ was reported high"). Those authors state that their approach represents a lower limit of pRONO ${ }_{2}$. Similarly, Brito et al. (2018), Schulz et al. (2018), Huang et al. (2019a, 2019b), and Avery et al. (2019), applied a fixed $R_{\mathrm{pRONO} 2}$ of 0.1 (citing Kiendler-Sharr et al. (2016)) for aircraft measurements in West Africa, aircraft measurements in the Amazon, rural forest and urban sites in Germany, and seasonal variations of indoor/outdoor air, respectively. The same method has been applied to laboratory studies of

175 biomass burning aging (Tiitta et al., 2016), composition from photooxidation of terpenes (Zhao et al., 2018; Pullinen et al., 2020), and the composition, optical properties, and aging of particles from a wide variety of biomass burning fuel sources (Cappa et al., 2020; McClure et al., 2020). However, in the latter study, the organic component is classified as "organonitrogen", assuming it includes contributions from both organic nitrate and nitro-organic (i.e. nitroaromatics) functional groups (and assumed to have the 180 same $\mathrm{NO}_{\mathrm{x}}^{+}$ratio).

In a regional and seasonal survey of $\mathrm{pRONO}_{2}$ in the SE US, Xu et al. (2015a) used the RoR concept. They estimated lower (2.2) and upper (4.4) limits for $R o R$ (or $R_{\mathrm{pRONO} 2}=0.1-0.2$ for their corresponding $R_{\mathrm{NH} 4 \mathrm{NO} 3}$ ) from literature reports of SOA formed from isoprene+ $\mathrm{NO}_{3}$ radicals (Bruns et al., 2010) and $\beta$-pinene $+\mathrm{NO}_{3}$ radicals (Fry et al., 2009; Bruns et al., 2010; Boyd et al., 2015), respectively. The rationale

185 for their approach is that, for their region of study, those two BVOC may represent major contributions to the mixture of $\mathrm{pRONO}_{2}$, and that the literature suggests there may be some source/composition dependence of $R_{\mathrm{pRONO} 2}$. For the same region, Chen et al. (2020) used bounds of $R_{\mathrm{pRONO} 2}(0.1-0.2)$, based on similar logic, however not derived from a $R o R$ calculation (however equivalent to a $R o R$ of 1.7-3.3). In a study of $\mathrm{pRONO}_{2}$ and $\mathrm{SOA}$ formation from Alberta oil sands extraction emissions from ground and

190 aircraft measurements, Lee et al. (2019) used the same bounds of $R_{\mathrm{pRONO} 2}(0.1-0.2)$, also not derived from a $R o R$ calculation and citing Xu et al (2015a) and Farmer et al. (2010) (equivalent to a RoR of 1.4-2.9 and 1.5-3.0 for the two datasets). The same methods as Xu et al. (2015a) were used (applying the same range of $R o R$ ), for measurements conducted in Houston, TX (Dai et al., 2019) and the North China Plain (Xu et al., 2021). However Xu et al. (2021) adjusted the $R_{\mathrm{NH} 4 \mathrm{NO} 3}$ to match the highest $\mathrm{NO}_{2}^{+} / \mathrm{NO}^{+}$ratios observed,

195 since it was substantially higher than the calibration $R_{\mathrm{NH} 4 \mathrm{NO} 3}$ (assuming for those periods, nitrate was purely $\mathrm{NH}_{4} \mathrm{NO}_{3}$ ). Thus, those five studies report their concentrations and inorganic/organic nitrate split accordingly, and report lower and upper bounds; however, Lee et al., (2019) largely focused on results for the upper limit $\mathrm{pRONO}_{2}$ concentrations for the scientific analysis (with equivalent RoRs: 1.4/1.5). Zhou et al. (2016), Zhu et al. (2016), and Yu et al. (2019) applied the RoR concept, citing a range of 2-4 from the

200 literature, and thus reported estimated lower/upper limit averages for contribution of $\mathrm{pRONO}_{2}$ to $\mathrm{pNO}_{3}$ in New York City (summer, 67\%/95\%), a background site in China (spring, 15/22\%), and an urban site in China (during spring, 13\%/21\%; summer, 41\%/64\%; autumn, 16\%/25\%), respectively. Similarly Zhu et al., (2021) applied the RoR concept, citing a range of 1.4-4.0 from the literature reporting upper(12\%)/lower(7.8\%) bounds for contribution of $\mathrm{pRONO}_{2}$ to $\mathrm{pNO}_{3}$ at a rural site in the North China

205 Plains during summer. Kostenidou et al. (2015), on the other hand, estimated the $R_{\mathrm{pRONO} 2}$ as the minimum $R_{\text {ambient }}$ observed in ambient data during the campaigns, resulting in effective RoRs of 5.6 and 12 for the two campaigns investigated. The same method is used by Reyes-Villegas et al. (2018) (using 46/30, and resulting in an effective RoR of 5) and Florou et al. (2017) (resulting in high effective RoRs of 14 and 15 for the two campaigns investigated). Other field studies have followed the methods of Fry et al. (2013)

210 (but using a few different fixed values for the RoR) using HR data (Ayres et al., 2015; Fisher et al., 2016; 
Lee et al., 2016; Palm et al., 2017; de Sá et al., 2018, 2019; Nault et al., 2018; Chen et al., 2021) or UMR data (Fry et al., 2018; Schulz et al., 2018).

\section{Survey of $\mathrm{NO}_{x}^{+}$ratios for particle-phase nitrates}

Given the numerous applications of $\mathrm{NO}_{\mathrm{x}}{ }^{+}$ratios to separate $\mathrm{pRONO}_{2}$ and $\mathrm{NH}_{4} \mathrm{NO}_{3}$ in $\mathrm{AMS}$ measurements,

215 yet many variations in methods and the numerical values used within each method, we have conducted a systematic survey of literature values and trends of $\mathrm{NO}_{x}^{+}$ratios for different nitrates. Such data compilation is aimed at evaluating the evidence that supports using a fixed $R o R$ to estimate $R_{\mathrm{pRONO} 2}$ from the calibration $R_{\mathrm{NH} 4 \mathrm{NO} 3}$ and to investigate the variability in $R_{\mathrm{pRONO} 2}$ produced from different sources. Figure 1 shows a compilation of $R o R$ values for $\mathrm{pRONO}_{2}$ derived for chamber-generated SOA, isolated

220 compounds (from chamber SOA or standards), and ambient measurements (using instrument comparisons or PMF separation). Figure 1 also shows the $R o R$ for the same data as a histogram and average, as well as the correlations of the $\mathrm{pRONO}_{2} \mathrm{vs} \mathrm{NH}_{4} \mathrm{NO}_{3}$ (inverse) $\mathrm{NO}_{\mathrm{x}}{ }^{+}$ratios. Details of the values used to compute the ratios and uncertainties, data sources, and any additional calculations for the information included in Fig. 1, are provided in Table S1.

225 The correlation between the $R_{\mathrm{pRONO} 2}$ and $R_{\mathrm{NH} 4 \mathrm{NO} 3}$ is fairly strong $\left(\mathrm{R}^{2}=0.54\right)$, considering the variety of data sources and substantial measurement uncertainties. It provides strong evidence that, to first order, the RoR method is consistent and supported by various methods, species/mixtures, instruments and operating conditions. The slopes of the linear regression constrained to a zero intercept using an ODR fit (2.66 \pm 0.11 ; assuming both variables contribute comparable uncertainty) is equivalent to an overall $R o R$

230 and is similar to the average of the individual $R o R$ datapoints (mean \pm standard error: $2.75 \pm 0.11$ ). Highlighted in the scatterplot in Fig. 1 are a couple of pairs of datapoints that are averages from several experiments conducted in our laboratory with two different AMS during two different years, with substantially different measured calibration $R_{\mathrm{NH} 4 \mathrm{NO} 3}$ while sampling the same chamber SOA (see S1.2). The trends in those points are similar to the overall trend and provide an example of the validity of the

$235 R o R$ method when only differences in instrument / operating conditions are present. Fig. S2 shows a complementary histogram to that in Fig. 1 for the $R_{\mathrm{pRONO} 2}$, without normalizing to $R_{\mathrm{NH} 4 \mathrm{NO} 3}$. Compared to the normalized values shown in Fig. 1 (i.e., RoRs), a factor of two larger relative variability is apparent, with a relative standard deviation of $49 \%$ compared to $25 \%$. Also of note is that the average value is $0.21 \pm 0.10$, twice as high as used in several literature studies. Finally, Fig. S3 shows a complementary plot

240 to the scatter plot in Fig. 1, with the inverse $\mathrm{NO}_{x}^{+}$ratios and axes swapped, which emphasizes different data and outliers, and yields similar but slightly higher $(<10 \%)$, RoR slopes and the same degree of correlation. While the representation in Fig. S3 uses the inverse $\mathrm{NO}_{\mathrm{x}}^{+}$ratio of that used throughout this manuscript, it places the $R_{\mathrm{NH} 4 \mathrm{NO} 3}$ on the x-axis, and thus a non-ODR fit may be appropriate under the assumption that most uncertainty is contributed by the $\mathrm{pRONO}_{2}$ ratios. The ODR and non-ODR fits

$245(2.83 \pm 0.12,2.66 \pm 0.12$, respectively) bracket the simple average value (2.75).

The compilation shown in Fig. 1 allows for consideration of dependencies of the RoR on species/mixtures or methods. Generally, the RoRs cluster around 1.5-4 for most studies. The variability within duplicated VOC-oxidant pairs (e.g., $\beta$-pinene+ $\mathrm{NO}_{3} \mathrm{SOA}$ ), similar compound classes (e.g., monoterpenes, isoprene, aromatics, long-chain alkanes or alkenes), or measurement methods (SOA

250 mixtures, isolated compounds, ambient measurements) is similar to the variability between such groupings. Therefore, given the data currently available, there does not appear to be any strong evidence 
to support any general chemical-dependence of the $\mathrm{pRONO}_{2} R o R$. While such a dependence may in fact exist, evaluation likely would require comparison of several organic nitrate molecules and/or mixtures systematically with the same instrumentation, operation conditions, and analysis methods, together with

255 duplication by different instruments.

Therefore, for applications and further evaluation described in this manuscript, we use the average and variability of the RoR determined from data highlighted in Fig. 1: 2.75 (mean) and standard deviation $( \pm 0.70,25 \%)$ or standard error $( \pm 0.11,4.0 \%)$. The $25^{\text {th }} / 50^{\text {th }} / 75^{\text {th }}$ percentiles are $2.12,2.73,3.12$ (interquartile range / median $+14 \% /-22 \%$ ). Given the approximate symmetry for the limited statistics

260 available, we treat the variability and uncertainty of the $R o R$ as approximately a normal distribution. The standard deviation should be considered an upper limit of the uncertainty of the applicable RoR and corresponds to the assumption that the variability in reported values is primarily attributable to true differences in ratios for different types of $\mathrm{pRONO}_{2}$. The lack of clear differences among different sources suggests that some of the variability may instead be instrument/operator related, and that the std. error

265 may be a more relevant characterization of the uncertainty. Complex mixtures of $\mathrm{pRONO}_{2}$ in the atmosphere would likely represent an ensemble of those ratios, and thus result in values closer to the average. In fact, for the limited (7) examples of ambient-derived RoRs, the average is similar and the variability somewhat smaller $(2.99 \pm 0.51, \pm 17 \%)$ compared to the overall survey data. The standard error of the overall survey can be considered a measure of the uncertainty under the assumption that the RoR is 270 invariable with source/type and the $R_{\mathrm{NH} 4 \mathrm{NO} 3}$ for an instrument is a perfect predictor of $R_{\mathrm{pRONO} 2}$. A separate manuscript will include further discussions on the $R o R$ uncertainty and applications to estimation of the overall nitrate apportionment and concentrations uncertainties.

We recommend the use of the average $R o R$ value computed here for future separations of $\mathrm{pRONO}_{2}$ and $\mathrm{NH}_{4} \mathrm{NO}_{3}$ in ambient aerosol with AMS until there is additional information available to support a

275 different or more complex formulation. On the other hand, where additional constraints on the expected $\mathrm{pRONO}_{2}$ ratio response may be available, a more specific value may be applied. For example, Takeuchi and Ng (2019) measured RoRs during dry chamber experiments for different SOA types where only $\mathrm{pRONO}_{2}$ nitrate was generated, and then used those system-specific $R o R$ s to separate $\mathrm{pRONO}_{2}$ and $\mathrm{NH}_{4} \mathrm{NO}_{3}$ during wet experiments where substantial $\mathrm{NH}_{4} \mathrm{NO}_{3}$ was also formed. We note that in a recent

280 study, Xu et al., (2021) inferred a substantial variability in $R_{\mathrm{pRONO} 2}$ for ambient measurements on diurnal timescales and with varying pollution levels; however, that relied on comparison of the $\mathrm{NO}_{\mathrm{x}}{ }^{+}$ratio method to a newly-proposed method using thermal denuder profiles, which they acknowledge has several potentially large uncertainties or biases that were not quantified.

It is important to emphasize that under strong influence of particle-phase nitrites or

285 semi/non-refractory nitrates (e.g., $\mathrm{NaNO}_{3}, \mathrm{Ca}\left(\mathrm{NO}_{3}\right)_{2}$ ), quantitative separation of nitrate types may be hindered or simply not feasible (Schroder et al., 2018). As a few studies have reported, nitrites and mineral nitrates produce substantially lower $\mathrm{NO}_{2}^{+} / \mathrm{NO}^{+}$ratios (thus higher $\mathrm{RoR}$ ) in the AMS. For example, RoRs of 10-60 for $\mathrm{NaNO}_{3}$ (Alfarra, 2004; Bruns et al., 2010; Hu et al., 2017b), 17 for $\mathrm{Ca}\left(\mathrm{NO}_{3}\right)_{2}$ (Alfarra, 2004), 3.9 for $\mathrm{Mg}\left(\mathrm{NO}_{3}\right)_{2}$ (Alfarra, 2004), 9.7 for $\mathrm{KNO}_{3}$ (Drewnick et al., 2015), and 300 for

$290 \mathrm{NaNO}_{2}$ (Alfarra, 2004) have been previously reported. We report additional measurements from our laboratory for $\mathrm{NaNO}_{3}, \mathrm{KNO}_{3}$, and $\mathrm{KNO}_{2}$ showing similarly high values. Table $\mathrm{S} 2$ provides additional details and Fig. S4 shows a graphical representation and comparison to $\mathrm{pRONO}_{2}$ for literature reports and our new data. Consequently, even if the expected ratios of other compounds was accurately known, 
apportioning the different nitrates or nitrites using a formulation like Eq. 1 would be under-constrained, as there would be more unknowns than equations. Therefore, care must be taken to screen for measurements that may be substantially influenced by such interferences (e.g., seasalt, dust). Additionally, during a recent aircraft campaign focused on biomass burning, we conducted regular calibrations with 4-nitrocatechol, a nitroaromatic (Pagonis et al., 2021). The $R o R$ was relatively similar to $\mathrm{pRONO}_{2}$ at 3.35 $\pm 0.81(1 \sigma$, standard deviation) (Table S2, Figs. S4, S5).

$300 \mathbf{4}$ Evaluation of calibration $\boldsymbol{R}_{\mathrm{NH} 4 \mathrm{NO} 3}$ and $\boldsymbol{R o R}$ using ambient data

A survey of $\mathrm{NO}_{\mathrm{x}}^{+}$ratios for multiple field studies is explored here in order to assess the framework of using measured calibration $R_{\mathrm{NH} 4 \mathrm{NO} 3}$ and a $R o R$ to apportion $\mathrm{NH}_{4} \mathrm{NO}_{3}$ and $\mathrm{pRONO}_{2}$ concentrations. See Sect. S1.1 and Table S3 for details and a summary of all field campaigns for which data is used within this manuscript. Figure 2 shows frequency distributions of $R_{\text {ambient }}$ for ambient aerosol from two

305 aircraft-based remote continental (SEAC ${ }^{4} \mathrm{RS}, \mathrm{DC} 3$ ) and two ground-based forest campaigns (SOAS, BEACHON-RoMBAS). The data is shown as the calibration $R_{\mathrm{NH} 4 \mathrm{NO} 3}$ divided by $R_{\text {ambient }}$, so that all data is comparable. For all campaigns, the large majority of the data fall between the $R_{\mathrm{NH} 4 \mathrm{NO} 3}(1$ on Fig. 2 , indicating all $\mathrm{NH}_{4} \mathrm{NO}_{3}$ ) and the RoR-determined $R_{\mathrm{pRONO} 2}\left(2.75\right.$ on Fig. 2, indicating all $\mathrm{pRONO}_{2}$ ). The small fraction of data outside that range may be due to a combination of instrument noise, drifts in the

310 instrument $\mathrm{NO}_{\mathrm{x}}^{+}$ratio response not captured by periodic calibrations, and/or the inability of the fixed $R o R$ to perfectly capture the $R_{\mathrm{PRONO} 2}$ response. However, these results show that under a large range of chemical conditions and instrument $R_{\mathrm{NH} 4 \mathrm{NO} 3}$ (spanning a factor of 2.4 for these campaign averages), the data are generally consistent with the RoR apportionment model. Figure $\mathrm{S} 6$ shows the same distributions as Fig. 2, except as simple frequency distributions, rather than weighted by mass concentration as in Fig.

315 2. The broadening and shift to the right for simple frequency distributions (compared to those weighted by mass concentration), reflect the typical trend that $\mathrm{pRONO}_{2}$ tends to constitute higher fractions of $\mathrm{pNO}_{3}$ when $\mathrm{pNO}_{3}$ is lower. Distributions are similar for other campaigns (not shown in Figs. 2, S6), as can be inferred from Figs. 5 and S9, which are discussed below.

The effects of estimating $R_{\mathrm{pRONO} 2}$ using time-variant vs constant $R_{\mathrm{NH} 4 \mathrm{NO} 3}$ is explored in Fig. S7. For the $320 \mathrm{SEAC}{ }^{4} \mathrm{RS}$ campaign, the flight-to-flight calibration $R_{\mathrm{NH} 4 \mathrm{NO} 3}$ were highly variable due to some instrument instability (range: $0.40-1.49$, mean \pm stdev: $0.80 \pm 0.31$; Figs. S8, S9e), compared to the very stable ratios measured during the other campaigns (see Fig. 2 caption). Therefore, two histograms are shown overlaid in Fig. S7, one normalized to flight-dependent calibration $R_{\mathrm{NH} 4 \mathrm{NO} 3}$ and the other normalized to the campaign-averaged $R_{\mathrm{NH} 4 \mathrm{NO} 3}$. For the standard frequency distributions (Fig. S7a), there is substantial

325 narrowing when using the flight-dependent ratios, indicating that application of the time-variant ratios provides better constraints on the instrument response to the $\mathrm{NH}_{4} \mathrm{NO}_{3}-\mathrm{pRONO}$ mixture. Conversely, normalizing to arbitrary $R_{\mathrm{NH} 4 \mathrm{NO} 3}$ would be expected to broaden the distribution. The most prominent differences for the mass concentration-weighted distributions (Fig. S7b) are largely due to data with high $\mathrm{NH}_{4} \mathrm{NO}_{3}$ concentrations where the measured $R_{\text {ambient }}$ were beyond the campaign-averaged $R_{\mathrm{NH} 4 \mathrm{NO} 3}$

330 (resulting in a substantial fraction of the distribution $<1$ ). There is also subtle broadening toward the $\mathrm{pRONO}_{2}$ portion of the distribution. These comparisons support that using the variable calibration $R_{\mathrm{NH} 4 \mathrm{NO} 3}$ better represents ambient $\mathrm{NH}_{4} \mathrm{NO}_{3}$ ratios (left side of plots) and tying $R_{\mathrm{pRONO} 2}$ to $R_{\mathrm{NH} 4 \mathrm{NO} 3}$ (i.e. using the $R o R$ method, rather than fixed $R_{\mathrm{PRONO} 2}$ ) better represents $\mathrm{pRONO}_{2}$ ratios (right side of plot). 
Additional support for the practice of using the measured calibration $R_{\mathrm{NH} 4 \mathrm{NO} 3}$ and anchoring the $335 R_{\mathrm{pRONO} 2}$ to those calibrations with a fixed $R o R$ can be drawn from the $R_{\text {ambient }}$ vs $\mathrm{pNO}_{3}$ plots shown in Fig. $\mathrm{S} 9 \mathrm{a} / \mathrm{b}$. Five studies shown in those figures had relatively constant (within each campaign), but differing (among campaigns; factor of 3.2 range), calibration $R_{\mathrm{NH} 4 \mathrm{NO} 3}$ (SOAR, MILAGRO, SOAS, BEACHON-RoMBAS, KORUS-AQ; 0.47, 0.84, 0.44, 0.30, 0.97, respectively). However, as $\mathrm{pNO}_{3}$ increases for the urban-influenced studies (SOAR, MILAGRO, SOAS, KORUS-AQ) or for the oxidation

340 flow reactor (OFR) measurements during SOAS (Fig. S8c), $R_{\text {ambient }}$ tends to approximately converge at the calibration $R_{\mathrm{NH} 4 \mathrm{NO} 3}$. This suggests that $\mathrm{NH}_{4} \mathrm{NO}_{3}$ in mixed ambient aerosol is well-represented by offline-calibrations for a range of conditions and instruments. Additionally, the corresponding average ratios at the lowest $\mathrm{pNO}_{3}$ concentration (same 5 studies in Fig. $\mathrm{S} 9 \mathrm{a} / \mathrm{b}$ ) converge at a similar range of ratios $(0.26,0.52,0.15,0.10,0.40$, respectively; range of 4.0$)$. If assuming that the low- $\mathrm{pNO}_{3}$ observed $R_{\text {ambient }}$

345 approximate pure $\mathrm{pRONO}_{2}$ ratios, a relatively narrower range is computed for an inferred $R o R$ (1.6-3.0, factor of $1.9 ; 2.36 \pm 0.63$ ), which is also similar to expected $R o R$ s (albeit low possibly due to urban ground studies never sampling pure $\mathrm{pRONO}_{2}$ ).

Further evidence supporting the use of calibration $R_{\mathrm{NH} 4 \mathrm{NO} 3}$ and the RoR using ambient data is presented in Sect. S2 using campaign datasets where the calibration $R_{\mathrm{NH} 4 \mathrm{NO} 3}$ showed large variability

350 (DAURE, SEAC ${ }^{4} \mathrm{RS}$ campaigns). Exploration of the $\mathrm{NO}_{\mathrm{x}}{ }^{+}$ratios $\mathrm{vs}_{\mathrm{pNO}}$ relationships showed similar relationships to those discussed above for campaigns where $R_{\mathrm{NH} 4 \mathrm{NO} 3}$ was constant or changed little, but with the curves shifting with the measured $R_{\mathrm{NH} 4 \mathrm{NO} 3}$. Similar values of $R o R$ to those presented in the literature survey in Sect. 3 were also inferred from the SEAC ${ }^{4} \mathrm{RS}$ dataset. Finally, both datasets were used to evaluate biases when using a fixed value of $R_{\mathrm{pRONO2}}$ vs estimation of a dynamic value using the $R o R$

355 method. Additional evidence from ambient measurements supporting use of calibration $R_{\mathrm{NH} 4 \mathrm{NO}_{3}}$ and the $R o R$ is presented in Sect. 5.2 where applications of PMF separation are discussed.

\section{Demonstrations of $R o R$ apportionment and comparisons to other measurements/methods}

\section{$5.1 \mathrm{pRONO}_{2}-\mathrm{NH}_{4} \mathrm{NO}_{3}$ separation compared to total (gas+particle) $\mathrm{RONO}_{2}$ (Tot-RONO$\left.)_{2}\right)$}

Figure 3 shows time series of $\mathrm{AMS} \mathrm{pRONO}_{2}$ and $\mathrm{NH}_{4} \mathrm{NO}_{3}$ concentrations for a SEAC ${ }^{4} \mathrm{RS}$ flight (RF16)

360 in the Southeast US. The nitrate components were apportioned according to Eqs. 2/3 and a RoR of 2.75.

"Total $\mathrm{RONO}_{2}$ " (gas+particle; hereafter Tot- $\mathrm{RONO}_{2}$ ) concentrations, as measured by thermal dissociation - laser induced fluorescence (TD-LIF) (Day et al., 2002; Perring et al., 2009), are shown for comparison. A wide range of sources were sampled including (and indicated by) biogenic (monoterpenes and/or isoprene and photochemical products such as IEPOX, MVK), anthropogenic (e.g., $\mathrm{NO}_{\mathrm{x}}, \mathrm{NO}_{\mathrm{y}}$, aromatics),

365 biomass burning (e.g., acetonitrile and $f_{60}$, an AMS tracer (Cubison et al., 2011)), likely agricultural, as well as mixtures of these sources or relatively clean free tropospheric air. Flight tracks are shown in Fig. S10 and approximate periods and corresponding source influences are listed in the caption. A large and variable range of $\mathrm{pNO}_{3}$ was observed $\left(<10 \mathrm{ng} \mathrm{m}^{-3}\right.$ or $<4 \mathrm{ppt}$ up to $\sim 5 \mu \mathrm{g} \mathrm{m}^{-3}$ or $\sim 1800 \mathrm{ppt}$ ) and ranging from $\mathrm{pRONO}_{2}$-dominated to $\mathrm{NH}_{4} \mathrm{NO}_{3}$-dominated. The $\mathrm{pRONO}_{2}$ and Tot- $\mathrm{RONO}_{2}$ tracked remarkably

370 closely. $\mathrm{NH}_{4} \mathrm{NO}_{3}$ concentrations exhibited more plume-like behavior, rapidly increasing and decreasing, often while both $\mathrm{pRONO}_{2}$ and Tot- $\mathrm{RONO}_{2}$ remained relatively constant or in some cases showed moderate and similar increases. Overall, $\mathrm{pRONO}_{2}$ was correlated with Tot- $\mathrm{RONO}_{2}\left(\mathrm{R}^{2}=0.49\right.$ for all data, $\mathrm{R}^{2}=0.69$ for data with $\left.f_{\mathrm{pRONO} 2}>0.3\right)$ with a regression slope of $0.029(0.033)$, indicating that on average $\sim 3 \%$ of $\mathrm{RONO}_{2}$ was in the particle phase (Fig. 3, bottom left). $\mathrm{NH}_{4} \mathrm{NO}_{3}$ showed little overall relationship 
375 to Tot- $\mathrm{RONO}_{2}$ beyond the trend that at higher altitudes, well above the boundary layer and outside of plumes, both concentrations tended to be low (Fig. 3, top and bottom right). Note that the reference $R_{\mathrm{NH} 4 \mathrm{NO} 3}$ in the particle nitrate apportionment here (in Eqs. 2/3) was 0.70 which was based on the measured calibration $R_{\mathrm{NH} 4 \mathrm{NO} 3}$ and PMF results (see Sect. 5.2 just below). Measured $R_{\mathrm{NH} 4 \mathrm{NO} 3}$ during calibrations in days bracketing this flight were 0.96 ( 2 days before) and 0.71 ( 1 day after). PMF results support a value

380 of 0.70 (see Sect. 5.2.2), which was used here since it was similar to the nearest calibrations and provides an additional constraint on the otherwise variable calibration $R_{\mathrm{NH} 4 \mathrm{NO} 3}$ characteristic of this campaign (see Sect. 4). Using a higher $R_{\mathrm{NH} 4 \mathrm{NO} 3}$ increases the $\mathrm{pRONO}_{2}$ vs Tot- $\mathrm{RONO}_{2}$ slope in Fig 4 (bottom left) and can improve the correlation a bit (mainly by moving the low values at low $f_{\mathrm{PRONO} 2}$ toward the regression line).

Taken together, these observations indicate that the AMS nitrate apportionment method effectively

385 separated $\mathrm{pRONO}_{3}$ and $\mathrm{NH}_{4} \mathrm{NO}_{3}$ over a large range of concentrations, relative contributions, and source influences. However, it is clear that there are limitations when the $f_{\mathrm{pRONO} 2}$ is very low (see Sect. 5.2). It would not be surprising if the $\mathrm{pRONO}_{2}$ and Tot- $\mathrm{RONO}_{2}$ showed large variability in relative ratios for different sources and locations, since: 1) $\mathrm{pRONO}_{2}$ is only a small subset of Tot- $\mathrm{RONO}_{2}$ and 2) changes in chemical composition and ambient conditions (e.g., OA concentration, temperature) could have large

390 impacts on gas-particle partitioning. However, in this case those effects do not appear to be large factors (or fortuitously cancel out), which in part may be due to relatively similar temperatures and OA concentrations combined with regionally consistent biogenic chemical sources of $\mathrm{RONO}_{2}$ compounds. Regardless of the exact reasons for the relatively invariant partitioning, it provides an excellent test case, since it would be very unlikely that the strong temporal/spatial correlation would be observed if there

395 were major artifacts in either or both the AMS and TD-LIF methods.

There were no measurements of inorganic nitrate onboard the aircraft with fast enough time resolution to compare with the rapidly changing $\mathrm{NH}_{4} \mathrm{NO}_{3}$ concentrations calculated from the AMS. Therefore, as a rough indicator of possible changes in the $\mathrm{NH}_{4}$ related to $\mathrm{NH}_{4} \mathrm{NO}_{3}$, "Excess $\mathrm{NH}_{4}$ " was calculated as the AMS-measured $\mathrm{NH}_{4}-1.2 \times \mathrm{SO}_{4}$ (as molar concentrations). A molar ratio of 1.2 was 400 roughly consistent with the observed ratio when no indications of $\mathrm{NH}_{4} \mathrm{NO}_{3}$ were present $\left(\mathrm{NH}_{4}=1.2 \times \mathrm{SO}_{4}\right)$ and substantial concentrations of $\mathrm{SO}_{4}$ were present, as shown in Fig. S11. That ratio represents a mixture of $\left(\mathrm{NH}_{4}\right)_{2} \mathrm{SO}_{4}$ and ammonium bisulfate or an ammonium balance $\left(\mathrm{NH}_{4 \_ \text {Bal }}\right)$ of $\sim 0.7\left(\mathrm{NH}_{4_{\text {BBal }}}=\right.$ molar ratio of $\mathrm{NH}_{4} /\left(\mathrm{NO}_{3}+2 \mathrm{SO}_{4}\right)$ ). During periods of elevated $\mathrm{NH}_{4} \mathrm{NO}_{3}$ concentrations, the measured $\mathrm{NH}_{4} \mathrm{NO}_{3}$ tracked the estimated "Excess $\mathrm{NH}_{4}$ " very closely with roughly half the concentration (Fig. S11). As suggested by

405 some negative "Excess $\mathrm{NH}_{4}$ " values and the factor of two between $\mathrm{NH}_{4} \mathrm{NO}_{3}$ and "Excess $\mathrm{NH}_{4}$ ", the assumption of constant $\mathrm{NH}_{4} / \mathrm{SO}_{4}$ ratios based on composition in the absence of $\mathrm{NH}_{4} \mathrm{NO}_{3}$ is not always valid (and not surprising) and clearly a more sophisticated thermodynamic model would be required to accurately predict $\mathrm{NH}_{4} \mathrm{NO}_{3}$ concentrations. Nonetheless, the similar features suggest the assignment of $\mathrm{NH}_{4} \mathrm{NO}_{3}$ is consistent with variations in the other AMS-measured inorganic compounds. The factor of 410 two suggests that $\sim$ half of the "Excess $\mathrm{NH}_{4}$ " was associated with sulfate and half with nitrate. During this flight, with the exception of the large biomass burning plume, the elevated $\mathrm{NH}_{4} \mathrm{NO}_{3}$ concentrations were observed when the aircraft flew at altitudes of $\sim 2000-4000 \mathrm{~m}$ and never during the low-altitude $(\sim 300-400 \mathrm{~m})$ legs (S20 bottom left/middle). This effect may have been due to the substantially cooler temperatures $\left(0-15^{\circ} \mathrm{C}\right.$ vs $\left.25-30^{\circ} \mathrm{C}\right)$ at those altitudes, favoring partitioning to the particle-phase, since 415 there did not appear to be any clear relationship between $\mathrm{NH}_{4} \mathrm{NO}_{3}$ and gas-phase $\mathrm{HNO}_{3}$ (Fig. S11, bottom 
right). Increases in available $\mathrm{NH}_{3}$ gas (not measured) could also be a factor (and consistent with both more sulfate- and nitrate-associated ammonium).

Another example for a different flight (RF18) during the SEAC ${ }^{4} \mathrm{RS}$ aircraft campaign is shown in Fig. $\mathrm{S} 12$, and was also selected due to large relative and absolute variability in calculated $\mathrm{pRONO}_{2}$ and $\mathrm{NH}_{4} \mathrm{NO}_{3}$ concentrations and diverse source types sampled (see Fig. S13 for flight track and description). Similarly, the pRONO 2 and Tot- $\mathrm{RONO}_{2}$ track remarkably well during periods when $\mathrm{NH}_{4} \mathrm{NO}_{3}$ concentrations are low or elevated and variable, and there is little correlation between $\mathrm{NH}_{4} \mathrm{NO}_{3}$ and Tot- $\mathrm{RONO}_{2}$. Overall, $\mathrm{pRONO}_{2}$ was correlated with Tot- $\mathrm{RONO}_{2}\left(\mathrm{R}^{2}=0.51\right.$ for all data, $\mathrm{R}^{2}=0.71$ for data with $\left.f_{\mathrm{pRONO} 2}>0.3\right)$ with a regression slope of $0.050(0.068)$, indicating that on average $\sim 5-7 \%$ of $\mathrm{RONO}_{2}$ 425 was in the particle phase (Fig. S12a, bottom left). The measured $\mathrm{NH}_{4} \mathrm{NO}_{3}$ tracked the estimated "Excess $\mathrm{NH}_{4}$ " reasonably well and showing similar sharp features (and roughly half the concentration; Fig. S12b, top). In contrast to RF16 discussed above, for RF18 most of the elevated $\mathrm{NH}_{4} \mathrm{NO}_{3}$ was observed in the warm boundary layer and often coincident with elevated $\mathrm{pRONO}_{2}$ (Fig. S12a,b).

\subsection{Positive Matrix Factorization separation of AMS nitrate}

\section{5.2.1 Prior studies using PMF for $\mathrm{pRONO}_{2}$ separation}

For the vast majority of analyses of AMS data using PMF, only traditional OA ions have been included in the input data matrices. Ions typically associated with nitrate, sulfate, ammonium, and chloride have generally been excluded, with the mindset that they are already separated as unambiguous inorganic species using the standard AMS analyses. However, since organic molecules (e.g., organic nitrates,

435 organosulfates, reduced organic nitrogen) can in fact produce some of the same ions as those inorganic species, inclusion with the OA ions in PMF analysis may allow for separation of inorganic and organic components, as well help identify associations with more well-established source factors.

A few studies have reported results for using PMF of ambient AMS spectra including both the OA and $\mathrm{NO}_{\mathrm{x}}^{+}$signals to quantify $\mathrm{pRONO}_{2}$ (and sometimes $\mathrm{NH}_{4} \mathrm{NO}_{3}$ ), with mixed results (Sun et al., 2012;

440 Hao et al., 2014; Xu et al., 2015a, 2021; Zhang et al., 2016; Kortelainen et al., 2017; Yu et al., 2019; Zhu et al., 2021). Additionally, a couple other studies have reported results where $\mathrm{NO}_{\mathrm{x}}^{+}$ions or calculated $\mathrm{pRONO}_{2}$ (using the $\mathrm{NO}_{\mathrm{x}}^{+}$ratio method) are included in PMF analysis, while not explicitly apportioning the inorganic-organic nitrate directly with the PMF results in the laboratory (Tiitta et al., 2016) and field (Kim et al., 2018; Reyes-Villegas et al., 2018). Details and discussions of those studies are presented in

445 Sect. S3 and key results are summarized in Table S4, as related to the PMF analyses.

\subsubsection{New results for PMF separation of $\mathrm{pRONO}_{2}$ and comparison to $\mathrm{RoR}$ method}

We conducted PMF on the combined $\mathrm{OA}$ and $\mathrm{NO}_{\mathrm{x}}^{+}$ion time series for the same two flights from the SEAC ${ }^{4} \mathrm{RS}$ campaign (as discussed above in Sect. 5.1; RF16, RF18) to test PMF separation of nitrates and the information it can provide, explore strategies, and compare to the RoR method. Details and an

450 extended discussion of that analysis is documented in Sect. S4 and key results are summarized in Table $\mathrm{S} 4$ alongside previous published analyses. A brief summary is provided here.

As discussed in Sect. 5.1, those two flights included sampling of a wide range of source types and concentrations. PMF was conducted initially on 1-s data; however, although robust overall factors were separated, results suggested that the $\mathrm{S} / \mathrm{N}$ was not adequate to apportion the $\mathrm{NO}_{\mathrm{x}}^{+}$ions to secondary factors 455 at ratios that reflected $\mathrm{pRONO}_{2}$ ratios. Therefore, all analyses discussed here are from 1-min 
measurements (which were more effective). Several strategies were used to explore the separation of OA, nitrate, and the $\mathrm{NO}_{\mathrm{x}}^{+}$ratios (in separate and combined factors), including: number of factors, varying FPEAK, upweighting and downweighting $\mathrm{NO}_{\mathrm{x}}^{+}$ions, bootstrapping, seeding, constraining $\mathrm{NO}_{\mathrm{x}}^{+}$ratios, and removing large biomass burning plumes. For both flights, five factors were robustly separated: $\mathrm{NH}_{4} \mathrm{NO}_{3}$, BBOA (biomass burning OA), IEPOX-SOA (IEPOX-derived SOA), LO-OOA (less-oxidized oxygenated OA), and MO-OOA (more-oxidized OOA) (Figs. S14-S28). See the Glossary and Sects. S3/S4 for more details on factor types. Generally, the best separations with the most information were for FPEAK at or near 0 , using standard $\mathrm{NO}_{\mathrm{x}}^{+}$ion $\mathrm{S} / \mathrm{N}$ (no downweighting/upweighting), not constraining $\mathrm{NO}_{\mathrm{x}}^{+}$ratios, not removing any plume data, and using bootstrapping to extract averages and assess 465 uncertainty/robustness.

The $\mathrm{NH}_{4} \mathrm{NO}_{3}$ factors and the $\mathrm{BBOA}$ factors had very similar $\mathrm{NO}_{\mathrm{x}}^{+}$ratios that were consistent with calibration $R_{\mathrm{NH} 4 \mathrm{NO} 3}$, with little variability across the 100 bootstrapping runs (Figs. S17, S25). While the apportionment of nitrate between the $\mathrm{NH}_{4} \mathrm{NO}_{3}$ and BBOA factors was very consistent across bootstrapping runs, changes in FPEAK had large effects on that relative apportionment as well as the 470 amount of $\mathrm{OA}$ ions in the $\mathrm{NH}_{4} \mathrm{NO}_{3}$ factor spectrum. For the OOA/SOA factors (IEPOX-SOA, LO-OOA, and MO-OOA) the $\mathrm{NO}_{\mathrm{x}}^{+}$ratios for LO-OOA and the combination of all three factors were consistent with expected $\mathrm{pRONO}_{2} \mathrm{NO}_{\mathrm{x}}^{+}$ratios using the RoR (Figs. S17, S25). Across bootstrapping runs, there was modest variability for those ratios (Figs. S17, S25), including some solutions where the LO-OOA had only $\mathrm{NO}^{+}$(but not for the combined OAA/SOA factor). The averages and standard deviations of the $\mathrm{NO}_{\mathrm{x}}^{+}$ 475 ratios for the combined OOA/SOA factor are included in the survey of $\mathrm{pRONO}_{2}$ RoRs (Fig. 1, Table $\mathrm{S} 1$ ). For calculation of $\mathrm{NH}_{4} \mathrm{NO}_{3}$ and $\mathrm{pRONO}$ concentrations, the nitrate contributions from the $\mathrm{NH}_{4} \mathrm{NO}_{3}$ and $\mathrm{BBOA}$ factors were summed as were the three OOA/SOA factors, respectively. The majority of the $\mathrm{pRONO}_{2}$ was contributed by the LO-OOA factor, followed by MO-OOA and then IEPOX-SOA (Figs. $\mathrm{S} 18$, S27). The variability in the factor spectra $\mathrm{NO}_{\mathrm{x}}^{+}$ratios and nitrate concentration apportionment across bootstrapping tended to follow the same trend (higher variability for factors with lower $\mathrm{pRONO}_{2}$ contribution; e.g., Figs. S17, S18a, S25, S27). Additionally, substantial trends were observed between factor spectra $\mathrm{NO}_{\mathrm{x}}^{+}$ratios and the amount of nitrate apportioned to that factor for some OOA/SOA factors. Bootstrapping and exploration of FPEAK was useful to investigate those dependencies.

Comparisons of $\mathrm{NH}_{4} \mathrm{NO}_{3}$ and $\mathrm{pRONO}_{2}$ concentrations using the $R o R$ and PMF methods are shown 485 for each flight in Figs. 4 and S12a as time series and scatter plots. For both flights there is very good agreement (near unity slope, $0.99-1.04$, and $\mathrm{R}^{2}>0.99$ ) between methods for $\mathrm{NH}_{4} \mathrm{NO}_{3}$, certainly in part due to the dominance of $\mathrm{NH}_{4} \mathrm{NO}_{3}$ during higher concentrations periods. There is reasonable agreement for $\mathrm{pRONO}_{2}$ (slopes of $0.86-1.50, \mathrm{R}^{2}$ of $0.51-0.65$ depending of the flight and fitting method; and improved to slopes of $1.04-1.42, \mathrm{R}^{2}$ of $0.68-0.84$ for $f_{\text {pRONO2 }}>0.3$ ) but with notable differences. $\mathrm{pRONO}_{2}$

490 concentrations tended to be noisier for the RoR method compared to the PMF method when nitrate was dominated by $\mathrm{NH}_{4} \mathrm{NO}_{3}$ or when $\mathrm{pNO}_{3}$ was very low. This may be due to the additional $\mathrm{S} / \mathrm{N}$ and constraints that the inclusion of the other OA ions provide, as well as the sensitivity (for both precision and accuracy) of apportionment for the $R o R$ method when ratios approach the $R_{\mathrm{NH} 4 \mathrm{NO} 3}$ limit. On the other hand, the PMF method may dampen some real variability due to the fact that the factor spectra are fixed

495 and cannot chemically evolve in the PMF model. In order to assess the true accuracy of either method, an independent and reliable determination of $\mathrm{pRONO}_{2}$ would be required. Finally, the comparison between 
the PMF-determined $\mathrm{pRONO}_{2}$ and the TD-LIF Tot-RONO${ }_{2}$ showed substantially-improved correlation (compared to using the RoR method) for one of the two flights (Fig. 4 vs 3).

\subsubsection{Summary of PMF method for nitrate separation}

500 The results from our investigation of PMF and analyses described in the literature summarized above highlight some general aspects, as well as some potential advantages and disadvantages of using PMF to apportion nitrate between organic and inorganic. One major potential advantage is that with PMF, the nitrates can be immediately associated with different source factors. On the other hand, the $\mathrm{NO}_{\mathrm{x}}{ }^{+}$ratio method can be used first and then correlations of nitrates with OA-only factors can be explored and even

505 apportioned. PMF may provide additional resolving power and $\mathrm{S} / \mathrm{N}$ by inclusion of associated OA ions, potentially more precisely separating nitrate concentrations, especially when either $\mathrm{pRONO} \mathrm{N}_{2}$ or $\mathrm{NH}_{4} \mathrm{NO}_{3}$ dominate the nitrate. Also, prior knowledge of the $\mathrm{NO}_{\mathrm{x}}{ }^{+}$ratio for $\mathrm{NH}_{4} \mathrm{NO}_{3}$ (or $\mathrm{pRONO}_{2}$ ) may not be necessary if the ratios are robustly resolved with PMF. Additionally, the $\mathrm{NO}_{\mathrm{x}}{ }^{+}$ratios resolved for $\mathrm{PMF}$ factors is a product for exploring ratios for ambient aerosol response, and validating application of offline

510 calibration $R_{\mathrm{NH} 4 \mathrm{NO} 3}$ and $R o R$ s derived largely from laboratory studies. PMF may also be useful in separating other species that produce $\mathrm{NO}_{x}{ }^{+}$ions (e.g. nitrites, nitro-organics, mineral nitrates), from just $\mathrm{NH}_{4} \mathrm{NO}_{3}$ and $\mathrm{pRONO}_{2}$, when they are present and have a unique $\mathrm{NO}_{\mathrm{x}}^{+}$ratio.

Some potential drawbacks or cautionary aspects are as follows. Since the PMF model requires fixed profile spectra, this means that nitrate-to-OA ratios are fixed for each factor. Therefore, if this ratio is in

515 fact substantially variable over the period/space of analysis, for example driven by processes such as pRONO${ }_{2}$ hydrolysis or gas-particle partitioning, substantial biases or uncertainties in nitrate apportionment can be introduced. While consideration of additional factors could help mitigate such effects, PMF is not designed to concisely separate profiles that are a continuum. Sometimes factors with clear $\mathrm{NH}_{4} \mathrm{NO}_{3}$ or $\mathrm{pRONO}_{2} \mathrm{NO}_{\mathrm{x}}^{+}$ratio signatures are not resolved. We suspect that datasets where neither

520 type of nitrate is dominant for some periods may be more susceptible to that issue; however, those issues may sometimes be resolvable with more extensive investigation with available PMF exploration tools (e.g., seeding, bootstrapping, FPEAK, constraining a $\mathrm{NH}_{4} \mathrm{NO}_{3}$ factor from offline calibrations).

Otherwise, apportioning nitrate using results with profile spectra that do not have clear nitrate signatures may introduce large uncertainties which are difficult to estimate. Variable $\mathrm{NO}_{\mathrm{x}}{ }^{+}$ratios due to instrument

525 drifts or changes (e.g., vaporizer bias voltage drifts or tuning) may lead to uncertainty in nitrate apportionment since PMF computes fixed factor spectra. In practice, for using the $\mathrm{NO}_{\mathrm{x}}{ }^{+}$ratio method this is not problematic, as long as regular offline $\mathrm{NH}_{4} \mathrm{NO}_{3}$ calibrations were performed. For PMF, separating the dataset into periods where the $\mathrm{NO}_{\mathrm{x}}^{+}$ratio was stable/constant and performing PMF separately for each period is one option to mitigate instrument drift issues; however, this can be very laborious if the dataset

530 requires separate analysis of multiple periods. Another option may be to apply the "rolling method" recently made available with $\mathrm{ME}-2 / \mathrm{SoFi}$, where a sub-window is moved across the PMF input along the time coordinate, allowing factor profiles to vary with each sub-window shift (Canonaco et al., 2021). Theoretically, offline calibration ratios of $\mathrm{NH}_{4} \mathrm{NO}_{3}$ may not be necessary for such application, although they would be preferable to have for validation.

535 A few other notable trends and observations are as follows. PMF-resolved $\mathrm{pRONO}_{2}$ often tends to have the largest contribution from (and association with) LO-OOA/SV-OOA, followed by MO-OOA/LV-OOA, especially for biogenically-influenced locations. That is consistent with $\mathrm{pRONO}_{2}$ 
forming in fresh SOA (i.e. LO-OOA/SV-OOA) and being partly lost as the OA ages and/or MO-OOA/LV-OOA consisting of a mix of aged OA, some of which was not associated with $\mathrm{pRONO}_{2}$.

Nitrate associated with BBOA tends to be dominantly $\mathrm{NH}_{4} \mathrm{NO}_{3}$; however, primary and secondary pRONO 2 associated with BBOA emission has been reported. When $\mathrm{NH}_{4} \mathrm{NO}_{3}$ factors are resolved, they tend to contain substantial contributions $(\sim 20-80 \%)$ of OA (non- $\left.\mathrm{NO}_{\mathrm{x}}^{+}\right)$ions. Generally, those non- $\mathrm{NO}_{\mathrm{x}}^{+}$ contributions seem to be higher for strongly biogenically-influenced measurements and less so during cooler wintertime periods when $\mathrm{NH}_{4} \mathrm{NO}_{3}$ comprises a larger fraction of nitrates. Our experience through

545 exploration of various approaches (e.g., upweighting the $\mathrm{NO}_{\mathrm{x}}^{+}$ions, increasingly positive FPEAK, increasing number of factors) suggests that efforts at "cleaning" the $\mathrm{NH}_{4} \mathrm{NO}_{3}$ factor tends to be ineffective and/or lead to degradation of the overall PMF solutions. Since the OA contained in the $\mathrm{NH}_{4} \mathrm{NO}_{3}$ tends to not be a large overall fraction of the OA, this does not appear to be a major issue. Finally, evidence suggests that inclusion of $\mathrm{NO}_{\mathrm{x}}^{+}$ions in PMF does not tend to have much influence on overall

550 OA-dominated factors (factor spectra nor concentration time series), which is not surprising given that their overall contribution to the $\mathrm{S} / \mathrm{N}$ among the many $\mathrm{OA}$ ions is fairly small. Consequently, there does not appear to be any drawbacks or complications associated with also including $\mathrm{NO}_{\mathrm{x}}^{+}$ions when running PMF on AMS data.

Overall, PMF appears to be a useful tool for apportioning nitrates and investigating their associations

555 with sources. The case for quantitative apportionment of nitrate with PMF is strongly bolstered when the $\mathrm{NO}_{\mathrm{x}}^{+}$ratios resolved for both the $\mathrm{NH}_{4} \mathrm{NO}_{3}$ factor and separate or combined $\mathrm{pRONO}_{2}$-associated factors are similar to $\mathrm{NH}_{4} \mathrm{NO}_{3}$ calibration and expected $\mathrm{pRONO}_{2} \mathrm{NO}_{\mathrm{x}}^{+}$ratios. When those criteria are not met, using the $\mathrm{NO}_{\mathrm{x}}^{+}$ratio method may be better, as it is likely less prone to such biases or ambiguities, and uncertainties can be better defined.

5605.3 Comparison of pRONO 2 quantification with AMS and other instruments in the lab and field

Several studies have reported quantitative comparisons of $\mathrm{pRONO}_{2}$ concentrations, as measured by AMS vs other instrumental methods (alternate AMS-based methods, FTIR, TD-(LIF/CRDS/CAPS), and FIGAERO-CIMS). Section S5 provides details and discussions and Table S5 presents a summary of key aspects of those comparisons. Overall, those comparisons show good agreement in most cases (1:1 within

565 known uncertainties) and substantial differences in a few cases (factors up to 2-4). In some of the cases where substantial differences were observed, possible explanations were discussed and sometimes explored. There do not appear to be any consistent reasons for the differences. In some of the field comparisons and all of the laboratory experiments, the nitrate sampled was dominated by (or exclusively) pRONO${ }_{2}$, and thus largely serve as a test of $\mathrm{pRONO}_{2}$ quantification (general calibration/quantification

570 factors, RIE, collection efficiency, etc.). Consequently, taken together the evidence available does not support use of an RIE for $\mathrm{pRONO}_{2}$ quantification with AMS that is significantly different from that measured for (and regularly calibrated with) $\mathrm{NH}_{4} \mathrm{NO}_{3}$. In order to narrow the uncertainties in $\mathrm{pRONO}_{2}$ quantification (in the field and laboratory), controlled laboratory-based intercomparisons of total and speciated organic nitrates using AMS and other methods are needed.

5756 Physical basis for $\mathrm{NO}_{\mathbf{x}}^{+}$ratios observed for nitrate types and variability among instruments As Farmer et al. (2010) points out, it is probable that a large fraction of $\mathrm{RONO}_{2}$ molecules thermally decompose to $\mathrm{RO}$ and $\mathrm{NO}_{2}$ at the AMS vaporizer after which $\mathrm{NO}_{2}$ gas is ionized. For example, the TD-LIF technique (and CRDS/CAPS equivalent methods) rely on quantitative thermal dissociation of 
$\mathrm{RONO}_{2}$ to $\mathrm{NO}_{2}$ in the gas phase, which occurs at $\sim 350{ }^{\circ} \mathrm{C}$ in $\sim 50 \mathrm{~ms}$ at near ambient pressures (Day et al., 580 2002). The timescale of evaporation/decomposition/ionization/detection for the AMS are on order tens of $\mu$ s (Drewnick et al., 2015; Jimenez et al., 2016); however, at $600^{\circ} \mathrm{C}$ the dissociation rate coefficient for $\mathrm{pRONO}_{2}$ is $\sim 4$ orders of magnitude larger (compared to $350^{\circ} \mathrm{C}$ ). That said, it is not clear what the pressures or temperatures of the gases are in the evaporation plume. Nevertheless, Farmer et al. note that thermal decomposition of $\mathrm{pRONO}_{2}$ to $\mathrm{NO}_{2}$ in the AMS would be consistent with the higher $\mathrm{NO}^{+} / \mathrm{NO}_{2}^{+}$

585 ratios observed for $\mathrm{pRONO}_{2}$ than $\mathrm{NH}_{4} \mathrm{NO}_{3}$. Their reasoning is that reported ratios of $\mathrm{NO}_{2}$ gas ionization (3.0) are substantially higher than those reported for $\mathrm{HNO}_{3}(0.5)$ gas as well as their measurements of particle-phase $\mathrm{NH}_{4} \mathrm{NO}_{3}$. Using the simplest assumption that only $\mathrm{NO}_{2}$ (from $\mathrm{RONO}_{2}$ thermal decomposition) and $\mathrm{HNO}_{3}$ (from $\mathrm{NH}_{4} \mathrm{NO}_{3}$ evaporation) are ionized would yield a $\mathrm{RoR}$ of 6 , which is double that observed. Moreover, fixed values would be expected for $\mathrm{pRONO}_{2}$ and $\mathrm{NH}_{4} \mathrm{NO}_{3}$ rather than

590 the observed range of $\sim 4$. Clearly, the behavior is more complicated than this simple model. Given that mass discrimination (ion transmission or detector efficiency differences) for the $m / z$ range of the $\mathrm{NO}^{+}$and $\mathrm{NO}_{2}{ }^{+}$ions is expected to be minor for the AMS (Hu et al., 2017b), the values and variability in $\mathrm{NO}_{\mathrm{x}}^{+}$ ratios likely originate in the vaporizer and/or ionizer region. As discussed in $\mathrm{Hu}$ et al. (2017b), the values and range of $\mathrm{NO}_{\mathrm{x}}^{+}$ratios observed for $\mathrm{NH}_{4} \mathrm{NO}_{3}$ (combined with other observations) are consistent with EI 595 from a combination of $\mathrm{HNO}_{3}, \mathrm{NO}_{2}$, and $\mathrm{NO}$ gases that are formed through thermal decomposition. They show the greatly-enhanced importance of such neutral gas-phase decomposition for measurements where a "capture vaporizer" is substituted for the standard AMS vaporizer. The capture vaporizer has a different geometry (optimized for limiting particle bounce) that results in longer gas-phase residence time near the hot vaporizer surfaces. Consequently, an order of magnitude lower $\mathrm{NO}_{2}^{+} / \mathrm{NO}^{+}$ratio is observed for

$600 \mathrm{NH}_{4} \mathrm{NO}_{3}(0.04-0.07)$, likely due to a shift in ionization toward primarily $\mathrm{NO}$ gas. Similar thermal decomposition processes would be expected for $\mathrm{RONO}_{2}$. However, thermal decomposition to $\mathrm{RO}$ and $\mathrm{NO}_{2}$ may occur much faster and always to near completion, given the thermal instability of the $\mathrm{O}-\mathrm{NO}_{2}$ bond and near absence of $\mathrm{C}_{\mathrm{x}} \mathrm{H}_{\mathrm{y}} \mathrm{O}_{\mathrm{z}} \mathrm{N}^{+}$fragments in $\mathrm{AMS} \mathrm{pRONO}_{2}$ spectra (Farmer et al., 2010). Hu et al. (2017a) report a large reduction in the $\mathrm{NO}_{2}^{+} / \mathrm{NO}^{+}$ratios for $\mathrm{pRONO}_{2}$ when using the capture vaporizer 605 compared to the standard vaporizer (with a $\mathrm{pRONO}_{2}$ ratio ten times lower than for $\mathrm{NH}_{4} \mathrm{NO}_{3}$ with the capture vaporizer).

As shown in Drewnick et al. (2015) and Jimenez et al. (2016), single-particle detection timescales for ions when sampling $\mathrm{NH}_{4} \mathrm{NO}_{3}$ show a range of a factor of two (and $\sim 25 \mu$ s differences), primarily with $\mathrm{NO}^{+}$being longer than $\mathrm{NO}_{2}^{+}$and $\mathrm{NH}_{\mathrm{x}}^{+}$ions. Those observations are interpreted as evidence for additional

610 processes occurring at longer timescales than flash vaporization at the nominal temperature such as vaporization at lower effective temperatures, slower vaporization or thermal decomposition, and adsorption/desorption from ionizer surfaces. They also showed that the signal-particle detection timescales were insensitive to vaporizer temperatures above $300^{\circ} \mathrm{C}$. On the other hand, Hu et al. (2017b) showed a small dependence of the $R_{\mathrm{NH} 4 \mathrm{NO} 3}$ on vaporizer temperature decreasing by $25 \%$ from $200^{\circ} \mathrm{C}$ to

$615800^{\circ} \mathrm{C}$, consistent with more thermal decomposition to $\mathrm{NO}_{2}$ and $\mathrm{NO}$ gases. Other studies have reported no dependence of $\mathrm{NO}_{\mathrm{x}}^{+}$ratios on vaporizer temperature $\left(\sim 200-600^{\circ} \mathrm{C}\right)$ for $\mathrm{pRONO}_{2}$-containing chamber SOA (Fry et al., 2009) or ambient (mixed nitrate) aerosol (Docherty et al., 2015). Overall, these observations point toward the timescales of interaction, and effects of spatial distribution of competing processes, playing a more important role in affecting observed ion ratios, rather than vaporizer 620 temperature. In part, this relative insensitivity to vaporizer temperature may be because the physical 
process of particle vaporization occurs at lower temperature than the nominal vaporizer temperature due to evaporative cooling (Saleh et al., 2017). Another observation that Hu et al. reported for using the capture vaporizer was that the vaporization timescales (based on UMR PToF distributions) for $\mathrm{NO}^{+}$was much longer than for $\mathrm{NO}_{2}^{+}$for $\mathrm{NH}_{4} \mathrm{NO}_{3}$, but the reverse for $\mathrm{pRONO}_{2}$. Such apparent spatiotemporal differences in thermal decomposition and ionization could potentially be used as another method for differentiating nitrates. However, low $\mathrm{S} / \mathrm{N}$ of $\mathrm{NO}_{2}^{+}$, differences in sizes and broader distributions for ambient aerosol nitrates, and the possibility that some of the differences $\mathrm{Hu}$ et al. observed were from $\mathrm{CH}_{2} \mathrm{O}_{\mathrm{x}}^{+}$, may seriously limit such approach and would require further evaluation (using HR-PToF).

A few other evaluations of $R_{\mathrm{NH} 4 \mathrm{NO} 3}$, described in Hu et al., (2017b) (using the standard vaporizer), 630 showed dependencies of $\mathrm{NO}_{\mathrm{x}}^{+}$ratios of only $<20 \%$ including varying the location on which particles impact the vaporizer (by horizontally translating the aerodynamic lens position) and varying the vaporizer bias voltage over ranges expected for typical AMS operation. On the other hand, varying the vaporizer bias voltage over a wider range, such as slightly beyond the settings where the aerosol signal peaks and where the gaseous "airbeam" signal peaks, can result in nearly a factor of two shift in the $R_{\mathrm{NH} 4 \mathrm{NO} 3}$ (Fig.

635 S29). This behavior reflects the ability of the vaporizer bias voltage tuning to preferentially sample ions produced in different regions of the ionizer. It has also been shown for the signals of other ions, such as $\mathrm{CO}_{2}^{+}$(Jayne et al., 2015). While proper tuning of the AMS vaporizer bias voltage typically aims at optimizing the aerosol signal, that may not always be performed by AMS operators and likely in some cases the airbeam signal may be optimized instead (which can be different than the particle signal peak as

640 in Fig. S29, although not always). Therefore, variability in this tuning parameter may explain a substantial fraction of the range in $\mathrm{NH}_{4} \mathrm{NO}_{3}$ (and possibly $\mathrm{pRONO}_{2}$ ) $\mathrm{NO}_{x}^{+}$ratios shown in Fig. 1. Another effect that appears to be able to substantially alter the $\mathrm{NO}_{\mathrm{x}}^{+}$ratios is related to exposure to high concentrations of $\mathrm{OA}$ for extended periods, possibly coating the vaporizer (and is possibly related to the "Pieber Effect" where nitrate aerosol produces $\mathrm{CO}_{2}^{+}$signal from interactions at the vaporizer surface), and will be discussed in a

645 future publication. Taking all the evidence available at present, the range in $\mathrm{NO}_{\mathrm{x}}^{+}$ratios for $\mathrm{NH}_{4} \mathrm{NO}_{3}$ and $\mathrm{pRONO}_{2}$ among instruments, settings, and operating conditions appears to be driven by changes in the amount of chemical decomposition and the overlap of those products with the ionizing electron beam. This aspect highlights the importance of periodic measurement of the $\mathrm{NO}_{\mathrm{x}}^{+}$ratios with a standard (i.e., $\mathrm{NH}_{4} \mathrm{NO}_{3}$ ), especially after making significant instrument changes, when quantifying $\mathrm{pRONO}_{2}$ and

$650 \mathrm{NH}_{4} \mathrm{NO}_{3}$ with the AMS.

\section{Multisite survey of inorganic/organic fractionation}

An overview of the inorganic vs organic nitrate apportionment for all of the campaigns discussed in this manuscript is shown in Fig. 5. The campaigns span: late-winter to summer across the northern hemisphere and wet/dry seasons near the equator; from ground level to the upper troposphere; and urban 655 to remote locations. Overall, the $f_{\mathrm{pRONO} 2}$ shows an inverse relationship with the $\mathrm{pNO}_{3}$, approaching $100 \%$ at low $\mathrm{pNO}_{3}$, primarily at rural/remote locations. At high $\mathrm{pNO}_{3}$ and strongly urban-influenced locations, the nitrate is dominantly $\mathrm{NH}_{4} \mathrm{NO}_{3}$. However, urban and urban-influenced locations can often exceed $50 \%$ contributions from $\mathrm{pRONO}_{2}$, when $\mathrm{pNO}_{3}$ is lower $\left(<1-2 \mu \mathrm{g} \mathrm{m}^{-3}\right)$. At the urban ground sites (MILAGRO, SOAR), the modulation of the variability in $\mathrm{pNO}_{3}$ tended to be driven by large increases in $\mathrm{NH}_{4} \mathrm{NO}_{3}$ from

660 photochemical production of $\mathrm{HNO}_{3}$ during morning to early afternoon, followed by evaporation at higher temperatures during afternoon driving concentrations to minima that were generally sustained through nighttime (Aiken et al., 2009; Docherty et al., 2011). At the rural/remote sites, nitrate is nearly always 
dominated by $\mathrm{pRONO}_{2}$ and with low concentrations. At the mid-latitude sites (BEACHON, SOAS), a large contribution to the variability in concentrations was attributed to nighttime production of $\mathrm{pRONO}_{2}$

665 from BVOC (Fry et al., 2013; Xu et al., 2015b). For the Amazon studies, substantial variability was observed on sub-day and synoptic timescales, especially during the lower-concentration wet season measurements, with episodic elevated inorganic contributions (de Sá et al., 2018, 2019). Thus, variability may have largely been driven by transport changes and large-scale regional processes; however, the factors controlling particle-phase nitrate for those studies have not been thoroughly explored. For

670 DAURE, an urban-downwind site with high $\mathrm{pNO}_{3}$, consistent diurnal patterns were not observed, and $\mathrm{pNO}_{3}$ variability was likely dominantly driven by variability in transport (Minguillon' et al., 2011; Zhang and Jimenez, 2021).

The aircraft campaigns span the entire range of the urban and rural/remote sites combined, since they include urban and biomass burning sampling, as well as rural/remote and free tropospheric sampling.

675 However, there are notable differences among them and compared to ground-based studies. A major difference is the shift toward lower $f_{\mathrm{pRONO} 2}$ or $\mathrm{pNO}_{3}$ in the intermediate ranges by factors of $\sim 2$ or $\sim 10$, respectively. The large divergence as $\mathrm{pNO}_{3}$ decreases from $\sim 2$ to $\sim 0.2 \mu \mathrm{g} \mathrm{m}^{-3}$ coincides with the range where the aircraft measurements show $\mathrm{NH}_{4 \_ \text {Bal }}$ transitions from balanced $\left(\mathrm{NH}_{4 \_ \text {Bal }} \sim 1\right)$ to a modest deficit in ammonium $\left(\mathrm{NH}_{4_{-} B a l} \sim 0.75-0.9\right)$ (see Fig. S30). Lower $\mathrm{NH}_{4_{-} B a l}$ can be indicative of more acidic aerosol

680 (Nault et al., 2021; Schueneman et al., 2021), making particle-phase $\mathrm{NH}_{4} \mathrm{NO}_{3}$ less thermodynamically stable. In comparison, the $\mathrm{NH}_{4 \text { Bal }}$ for the ground-based urban-influenced studies, (SOAR, MILAGRO, DAURE) were consistently near unity (Aiken et al., 2009; Docherty et al., 2011; this work for DAURE, not shown). However, such effects alone would result in higher $f_{\mathrm{pRONO} 2}$ in the aircraft studies, not lower as observed, due to sulfate not balanced by ammonium and acidity making ammonium nitrate

685 thermodynamically unstable. Therefore, other factors must be at play, such as very different sources being sampled, lower temperatures and higher $\mathrm{RH}$ for the aircraft measurements (making $\mathrm{NH}_{4} \mathrm{NO}_{3}$ more thermodynamically stable; see Sect. 5.1, Fig. S11), dilution shifting the curves, or higher acidity shortening the lifetime of $\mathrm{pRONO}_{2}$ (such as accelerating hydrolysis). At the lower range of $\mathrm{pNO}_{3}(<0.2$ $\mu \mathrm{g} \mathrm{m}^{-3}$ ) the $f_{\text {PRONO2 }}$ is substantially different following the order KORUS $<\mathrm{DC} 3<\mathrm{SEAC}^{4} \mathrm{RS}$. Considering 690 again the $\mathrm{NH}_{4 \text { Bal }}$ (Fig. S30), for SEAC ${ }^{4} \mathrm{RS}$ the aerosol inorganics are much less balanced by ammonium $\left(\mathrm{NH}_{4-B a l} \sim 0.08-0.75\right)$ compared to DC3 $\left(\mathrm{NH}_{4 \_ \text {Bal }} \sim 0.5-0.8\right)$ and KORUS $\left(\mathrm{NH}_{4 \_ \text {Bal }} \sim 0.5-0.9\right)$ at the lower $\mathrm{pNO}_{3}$ range, suggesting a possible role of acidity and $\mathrm{NH}_{3}$ availability. On the other hand, it does not appear that acidity plays a dominant role in favoring the high $f_{\mathrm{PRONO} 2}$ at the rural/remote ground-based studies, as BEACHON tended to be fully balanced $\left(\mathrm{NH}_{4_{-} B a l} \geq 0.9\right)$ while SOAS was not $\left(\mathrm{NH}_{4_{B} B a l} \sim\right.$

695 0.5-0.7) (Fry et al., 2013; Hu et al., 2016).

Many different chemical and physicochemical processes interplay to control the concentrations and relative proportions of $\mathrm{NH}_{4} \mathrm{NO}_{3}$ and $\mathrm{pRONO}_{2}$ in the atmosphere. Fig. 6 shows a schematic of those key processes. The differentiation can be viewed as effectively beginning with the branching of the radical-radical reaction of $\mathrm{NO}_{\mathrm{x}}$ with $\mathrm{OH}$ vs $\mathrm{RO}_{2}$ or VOCs $\left(\mathrm{NO}+\mathrm{RO}_{2}, \mathrm{NO}_{2}+\mathrm{RC}(\mathrm{O}) \mathrm{O}_{2}, \mathrm{NO}_{3}+\mathrm{RC}=\mathrm{CR}^{\prime}\right)$ to

700 produce gas-phase $\mathrm{HNO}_{3}$ vs $\mathrm{RONO}_{2}$. The relative amount of these pathways can vary widely, in large part controlled by relative amounts of $\mathrm{NO}_{x}$ concentrations compared to VOC reactivity; the $\mathrm{RONO}_{2}$ formation pathway can become dominant below modest $\mathrm{NO}_{\mathrm{x}}$ concentrations, particularly at biogenically-influenced rural sites (e.g., Browne and Cohen, 2012; Romer, 2018). However, the partitioning of $\mathrm{HNO}_{3}$ and $\mathrm{RONO}_{2}$ into the particle phase can depend on numerous factors such as $\mathrm{NH}_{3}$ availability, $\mathrm{RH}$, temperature, particle 
705 acidity, $\mathrm{RONO}_{2}$ volatility, or OA concentrations. Subsequent chemical, photochemical, evaporation, and deposition losses of gas and particle components will also exert controls on concentrations and lifetimes. In large part, the general trend shown in Fig. 5, over more than three orders of magnitude $\mathrm{pNO}_{3}$, may be driven by the ability of $\mathrm{HNO}_{3}$ formation in the presence of sufficient $\mathrm{NH}_{3}$ at increasing pollutions levels (i.e., $\mathrm{NO}_{\mathrm{x}}$ ) to overwhelm more modest $\mathrm{pRONO}$ formation, combined with the high volatility of $\mathrm{NH}_{4} \mathrm{NO}_{3}$ 710 prone to evaporation upon dilution. In contrast, at rural and remote locations, the formation of $\mathrm{RONO}_{2}$ becomes more favorable, producing $\mathrm{pRONO}_{2}$ of which a substantial portion is not prone to rapid chemical or evaporative loss, thus dominating widespread background nitrate composition. However, this is a very simplified picture of the complex processes at play and more detailed investigations combining corresponding measurements with modeling to better understand the dominant processes controlling the

715 trends shown in Fig. 5 are needed. In a recent study of eleven aircraft campaigns from throughout the globe, Nault et al. (2021) showed overall trends of decreasing $\mathrm{pH}$ and $\mathrm{NH}_{4 \_ \text {Bal }}$ with remoteness (as indicated by decreasing total inorganic $\mathrm{PM}_{1}$ ), which was not well-represented in many current models. While there may be some connections between that phenomena and the one shown in Fig. 5 (e.g., via acidity and $\mathrm{NH}_{3}$ availability), inorganic $\mathrm{PM}_{1}$ concentration is more closely related to remoteness than

$720 \mathrm{pNO}_{3}$, as it is often dominated by sulfate, which is less chemically reactive and less volatile than $\mathrm{pRONO}_{2}$ and $\mathrm{NH}_{4} \mathrm{NO}_{3}$, and its formation is less coupled to VOC conditions. For a ground-based study in a Chinese megacity during fall, a strong trend of increasing inorganic fraction of $\mathrm{pNO}_{3}$ with increasing calculated aerosol $\mathrm{pH}(\mathrm{pH}=1.5-3.5)$ was observed, which was attributed to numerous coincident factors during pollution episodes favoring $\mathrm{NH}_{4} \mathrm{NO}_{3}$ precursor availability and gas-to-particle partitioning (Chen et al.,

725 2021).

We note that the data included in Fig. 5 are generally weighted toward warmer periods or regions. Xu et al. (2015a) reported wintertime (within Nov-Feb) measurements of organic and inorganic nitrate at two urban and one rural site in the southeast US. Campaign averages of $\mathrm{pNO}_{3}$ ranged $0.8-1.4 \mu \mathrm{g} \mathrm{m}^{-3}$ (with $1 \sigma$ variability of $\pm 90-100 \%$ ) and average $f_{\mathrm{pRONO} 2}$ was $0-30 \%$ across the sites and the apportionment methods 730 considered. $\mathrm{pNO}_{3}$ and inorganic nitrate showed strong diurnal cycles, peaking mid-morning with minima mid-to-late afternoon. Nitrate apportionment vs $\mathrm{pNO}_{3}$ was not reported, so it is unclear if similar trends to those in Fig. 5 were present (e.g., if $f_{\text {pRONO2 }}$ increased during afternoon $\mathrm{pNO}_{3}$ minima). However, on average all three campaigns fell in the chemical coordinate space of the urban-influenced studies shown in Fig. 5. The fact that the rural site was similar to the urban sites may be due to the cooler winter

735 temperature (and higher RH) as well as reduced biogenic influences, compared to warm rural studies shown in Fig. 5. A few other studies have shown AMS data as supplementary material, that suggest similar relationships to those in Fig. 5 for individual studies. Those include plots of $\mathrm{NO}^{+}{\mathrm{vs} \mathrm{NO}_{2}}^{+}$ions which appear to have higher ratios of $\mathrm{NO}^{+} / \mathrm{NO}_{2}{ }^{+}$at lower signals (Docherty et al., 2015; Zhou et al., 2016) or decreasing $\mathrm{NO}_{2}^{+} / \mathrm{NO}^{+}$ratios with decreasing $\mathrm{pNO}_{3}$ (Kiendler-Scharr et al., 2016). Additionally, a recent

740 analysis of three datasets in the North China Plain (urban summer/winter, rural winter), showed a strong decreasing trend in $f_{\mathrm{PRONO} 2} \mathrm{Vs} \mathrm{PM}_{1}$ during the urban summer measurements and weak trends for the wintertime measurements (and lower overall $f_{\mathrm{pRONO} O 2}$ ) (Xu et al., 2021). Those observations are generally consistent with the trends with $\mathrm{pNO}_{3}$ during summer and with seasonality discussed above. 


\section{Conclusions}

We have explored the viability of using the $\mathrm{NO}_{\mathrm{x}}^{+}$ion ratios produced in the AMS spectrum from nitrates to separate and quantify $\mathrm{NH}_{4} \mathrm{NO}_{3}$ and $\mathrm{pRONO}_{2}$ concentrations in ambient aerosols. The use of $\mathrm{NH}_{4} \mathrm{NO}_{3}$ calibration $\mathrm{NO}_{\mathrm{x}}^{+}$ratios and an inferred $\mathrm{NO}_{\mathrm{x}}^{+}$ratio for $\mathrm{pRONO}$ that tracks the $\mathrm{NH}_{4} \mathrm{NO}_{3}$ ratio

("Ratio-of-Ratios") is investigated and tested. An extensive range of data and approaches are utilized for

750 this investigation including: a diverse collection of ambient field datasets, chamber studies, oxidation flow reactors, pure compounds, comparisons to AMS PMF methods and other $\mathrm{pRONO}_{2}$ or related measurements, and a compilation of a broad literature survey.

It is shown that the method is robust and effective under typical ambient sampling conditions. Methods and practical considerations for calculating concentrations are described. The Ratio-of-Ratios

$755 \mathrm{NO}_{\mathrm{x}}{ }^{+}$ratio method produced similar results to conducting PMF on the expanded mass spectra series (including both $\mathrm{OA}$ and $\mathrm{NO}_{\mathrm{x}}^{+}$ions) to apportion nitrates. While using the PMF method may have advantages of improved signal-to-noise and can provide connections between $\mathrm{pRONO}_{2}$ and $\mathrm{OA}$ sources, it is much more labor-intensive and can lead to substantial biases if not explored and applied carefully.

A broad survey of nitrate apportionment shows a pervasive relationship of increasing (decreasing)

$760 \mathrm{pRONO}_{2}$ relative contributions to nitrate with decreasing (increasing) total nitrate concentrations. Those trends generally follow from urban-influenced to rural/remote regions. However, there are some clear differences in those trends between different sampling regions and conditions.

Previous studies reporting nitrate quantification using $\mathrm{AMS} \mathrm{NO}_{\mathrm{x}}^{+}$ratios (or $\mathrm{PMF}$ using $\mathrm{NO}_{\mathrm{x}}^{+}$ions) have employed a range different approaches and assumptions, based on generally limited information. In 765 some instances, likely substantial biases were present and rarely has the accuracy of the results been considered. This investigation will help provide a more consistent, accurate and transparent approach to quantification and exploration of bulk particle-phase nitrates in the atmosphere with AMS (and related instrumentation). Comparisons of this method to other instrumentation capable of quantifying bulk or speciated particle-phase organic nitrates, in the laboratory and field, should be an ongoing focus to help

770 better constrain uncertainties, identify biases, and improve this method (and others).

\section{Acknowledgements}

This research was supported by NASA grants 80NSSC18K0630 and 80NSSC19K0124, as well as US NSF grant NSF AGS-1822664, NOAA grant NA18OAR4310113. BBP acknowledges support from a US

775 EPA STAR Graduate Fellowship (FP-91761701-0). This work has not been formally reviewed by the US EPA. The views expressed are solely those of the authors, and the US EPA does not endorse any products or commercial services mentioned in this work. We thank John Crounse and Paul Wennberg (Caltech) for use of nitric acid measurements in Figs. S11, S12. 
Figures
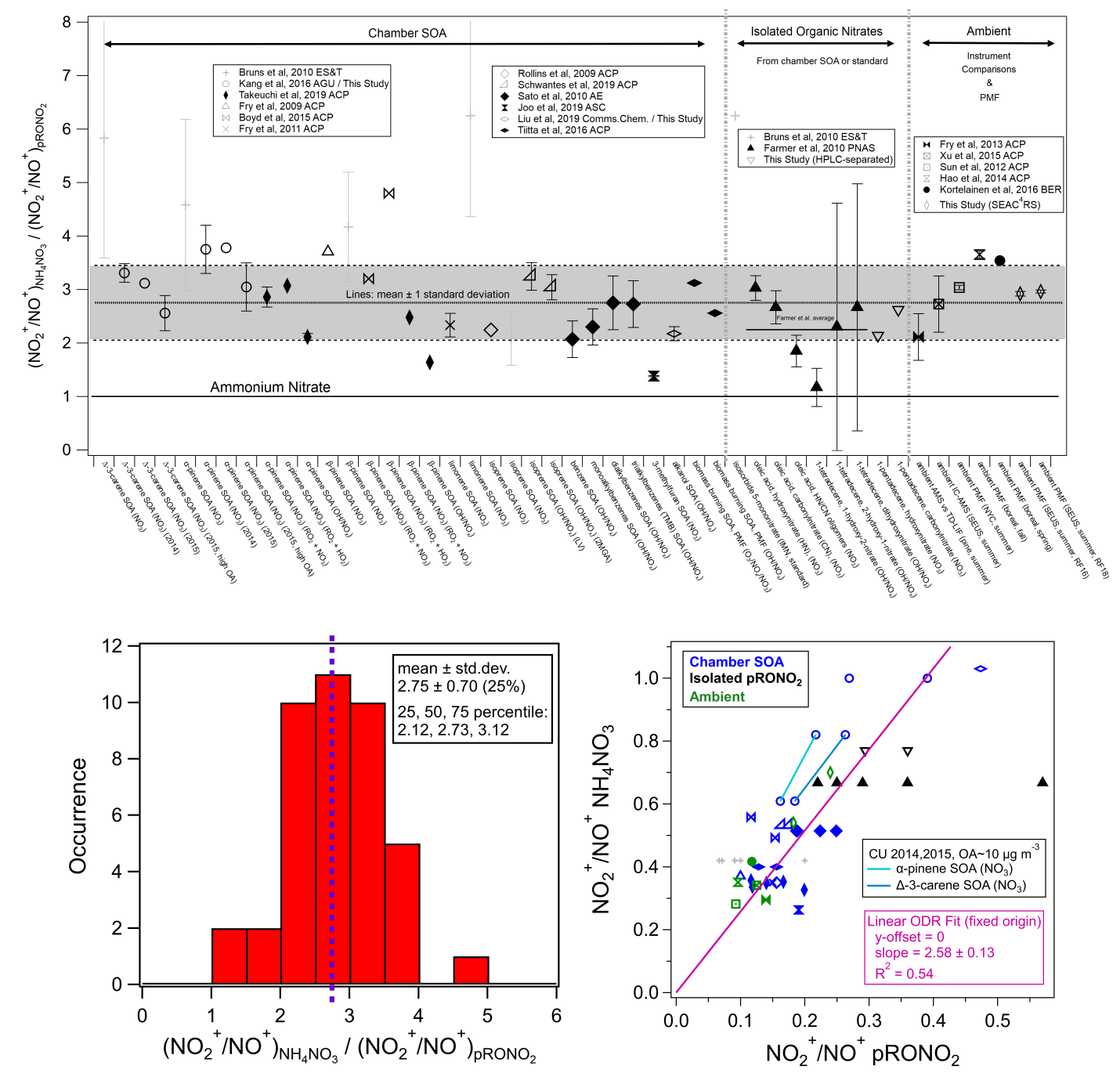

785 Figure 1. (Top) Survey of "Ratio-of-Ratios" $(R o R)$ computed from $\mathrm{NO}_{2}{ }^{+} / \mathrm{NO}^{+}$ratios reported for chamber studies, pure organic nitrates, and field observations (using instrument comparisons or PMF separation). The mean (2.75) and standard deviation $( \pm 0.70, \pm 25 \%)$ are also shown (standard error for $\mathrm{n}=41: \pm 0.11$, $\pm 4.0 \%$ ). The light grey shading ( "+" markers) indicates data that were not used in the average here, nor in the fits below (see Table S1 for rationale). Details of the values used to compute the ratios and

790 uncertainties, data source, and any additional calculations for the information included in Figure 1 are provided in Table S1. (bottom left) Histogram and statistics of RoR. (bottom right) scatter plot of $R_{\mathrm{NH} 4 \mathrm{NO} 3}$ vs. $R_{\mathrm{pRONO} 2}$. Linear least-squares lines are shown with orthogonal distance regression ODR fit (with intercept constrained through the origin since offsets from unconstrained fits were not significant and for consistency with apportionment equation). The data connected by cyan and green lines are averages from 795 experiments conducted in our lab with two different AMSs (with substantially different calibration 
$R_{\mathrm{NH} 4 \mathrm{NO} 3}$ ) while sampling the same SOA particles produced using the same two precursors mixtures. See Fig. S3 for the equivalent scatter plot, instead using $\mathrm{NO}^{+} / \mathrm{NO}_{2}^{+}$ratios and swapping the axes $\left(R_{\mathrm{pRONO} 2} \mathrm{VS}\right.$ $\left.R_{\mathrm{NH} 4 \mathrm{NO} 3}\right)$.
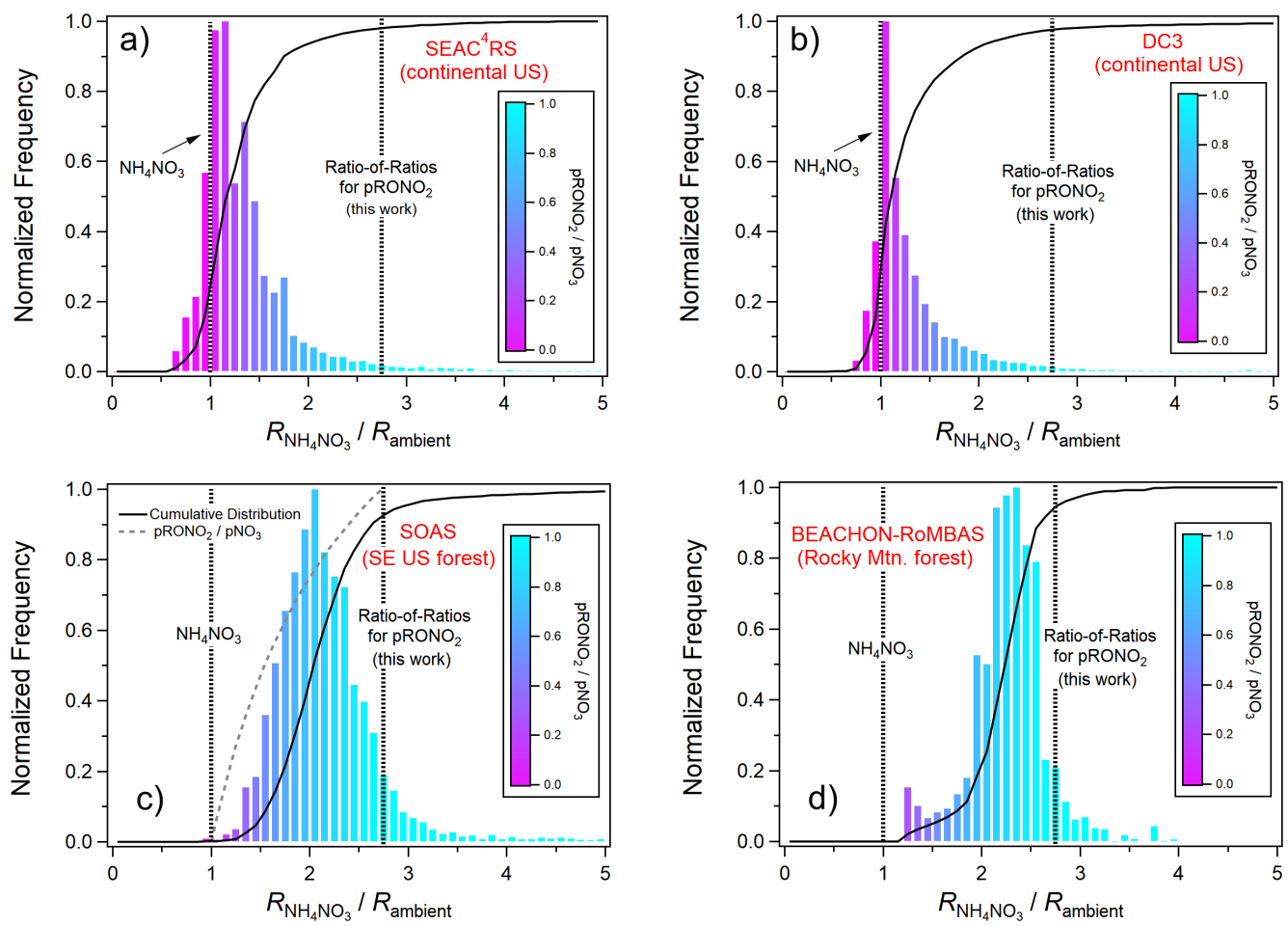

805 Figure 2. Histograms of ambient $\mathrm{NO}_{\mathrm{x}}{ }^{+}$ratios for aircraft and ground-based campaigns. The data is shown as the calibration $R_{\mathrm{NH} 4 \mathrm{NO} 3}$ divided by $R_{\text {ambient }}$, so that all data are on the same reference coordinates. The histograms are weighted by $\mathrm{pNO}_{3}$ concentration. Cumulative distributions are shown in all plots and an additional curve only on the SOAS panel shows the $f_{\mathrm{pRONO} 2}\left(\mathrm{pRONO}_{2} / \mathrm{pNO}_{3}\right)$ for these coordinates (would be identical on all panels). The data used were 1-minute averages and screened for $\mathrm{pNO}_{3}$ detection limits

810 for the aircraft campaigns (SEAC ${ }^{4} \mathrm{RS}, \mathrm{DC} 3$ ), and 1-hour averages for the ground-based campaign (SOAS, BEACHON-RoMBAS). Measured $R_{\mathrm{NH} 4 \mathrm{NO} 3}$ for these studies were as follows: SEAC ${ }^{4} \mathrm{RS}$ (range 0.40-1.49, mean and stdev. 0.80 \pm 0.31$)$; DC3 (0.71 \pm 0.04$)$; SOAS (0.44 \pm 0.02$)$; BEACHON-RoMBAS: $(0.295 \pm 0.005)$. See Fig. S6 for equivalent plots where distributions are not weighted by mass concentration). 

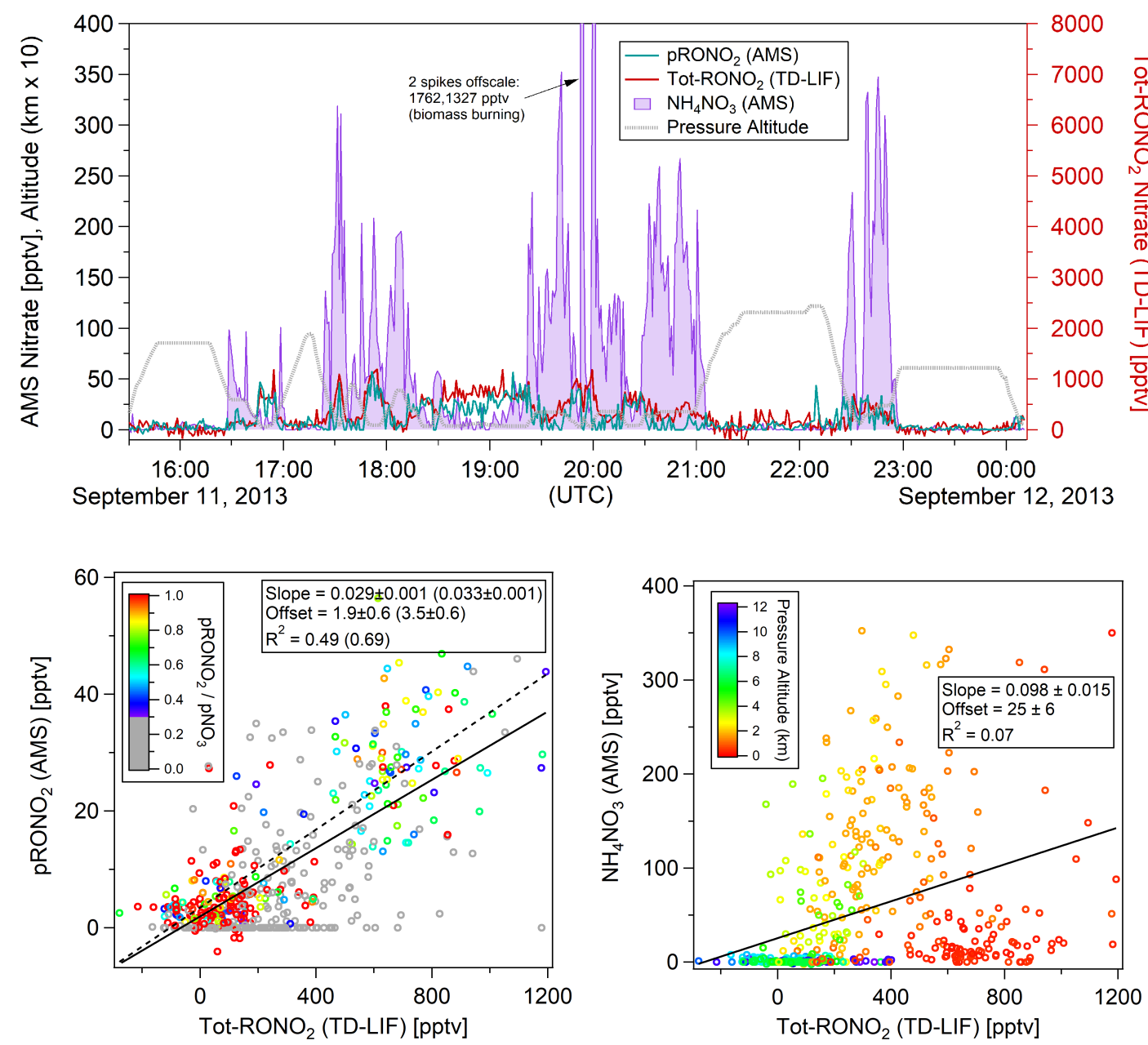

820 Figure 3. Comparisons of AMS pRONO 2 and $\mathrm{NH}_{4} \mathrm{NO}_{3}$ with TD-LIF total (gas + particles) organic nitrate (Tot- $\mathrm{RONO}_{2}$ ) during a SEAC ${ }^{4} \mathrm{RS}$ flight (RF16) in the Southeast US (1-min averages). The time series (top) and scatterplots of $\mathrm{pRONO}_{2}$ (bottom left) or $\mathrm{NH}_{4} \mathrm{NO}_{3}$ (bottom right) vs Tot- $\mathrm{RONO}_{2}$ are shown. Measured calibration $R_{\mathrm{NH} 4 \mathrm{NO} 3}$ (consistent with PMF results in Sect. 5.2.2), a RoR of 2.75, and Eqs. $2 / 3$ were used to apportion the AMS nitrate. Linear least-squares lines are orthogonal distance regression

825 (ODR). For the $\mathrm{pRONO}_{2}$ vs Tot- $\mathrm{RONO}_{2}$ plot (bottom left), an additional line (dotted) and fits (parentheses) are shown for data including only when $f_{\mathrm{pRONO} 2}\left(\mathrm{pRONO}_{2} / \mathrm{pNO}_{3}\right)$ is greater than 0.3 (and datapoints with $f_{\mathrm{pRONO} 2}<0.3$ are greyed). Figure $\mathrm{S} 10$ shows the flight track and timing of different source types sampled. 

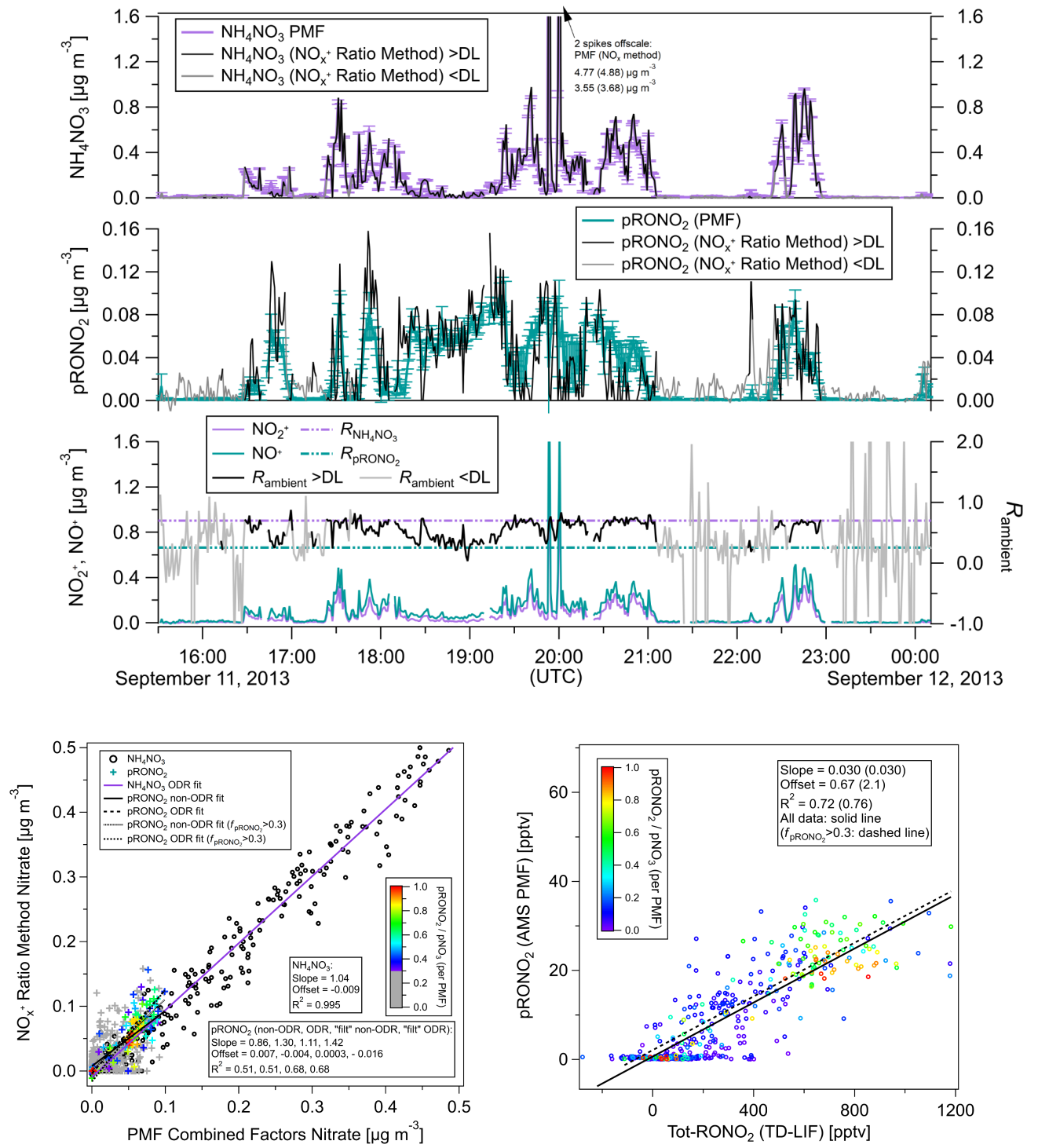

Figure 4. Comparison of $\mathrm{NO}_{\mathrm{x}}^{+}$ratio vs $\mathrm{PMF}$ methods for calculation of $\mathrm{NH}_{4} \mathrm{NO}_{3}$ and $\mathrm{pRONO}_{2}$ as time series (top three panels) and as scatter plots (bottom left) for same flight shown in Fig. 3. Concentration time series calculated using the $R o R$ method (as well as the measured $\mathrm{NO}_{\mathrm{x}}^{+}$signals and ratios) are shown for all data as well as only when above the $R_{\text {ambient }}$ detection limit (DL). Bottom right: $\mathrm{PMF} \mathrm{pRONO}_{2} \mathrm{vs}$ TD-LIF Tot- $\mathrm{RONO}_{2}$ (equivalent to Fig. 3 bottom left, which instead shows $\mathrm{pRONO}_{2}$ from $R o R$ method). $\mathrm{pRONO} 2$ in scatterplots are colored by the $f_{\mathrm{pRONO} 2}\left(\mathrm{pRONO}_{2} / \mathrm{pNO}_{3}\right)$ as computed using the PMF method. Regression line fits/slopes/offsets and correlation coefficients are shown using different fitting methods and criterion as indicated in legends (where "filt" indicates fits where data is limited to $f_{\mathrm{pRONO} 2}>0.3$ ). All 840 PMF-derived concentrations are averages (and standard deviations) of 100 bootstrapping runs (similar results using seeding runs shown in Fig. S21). 


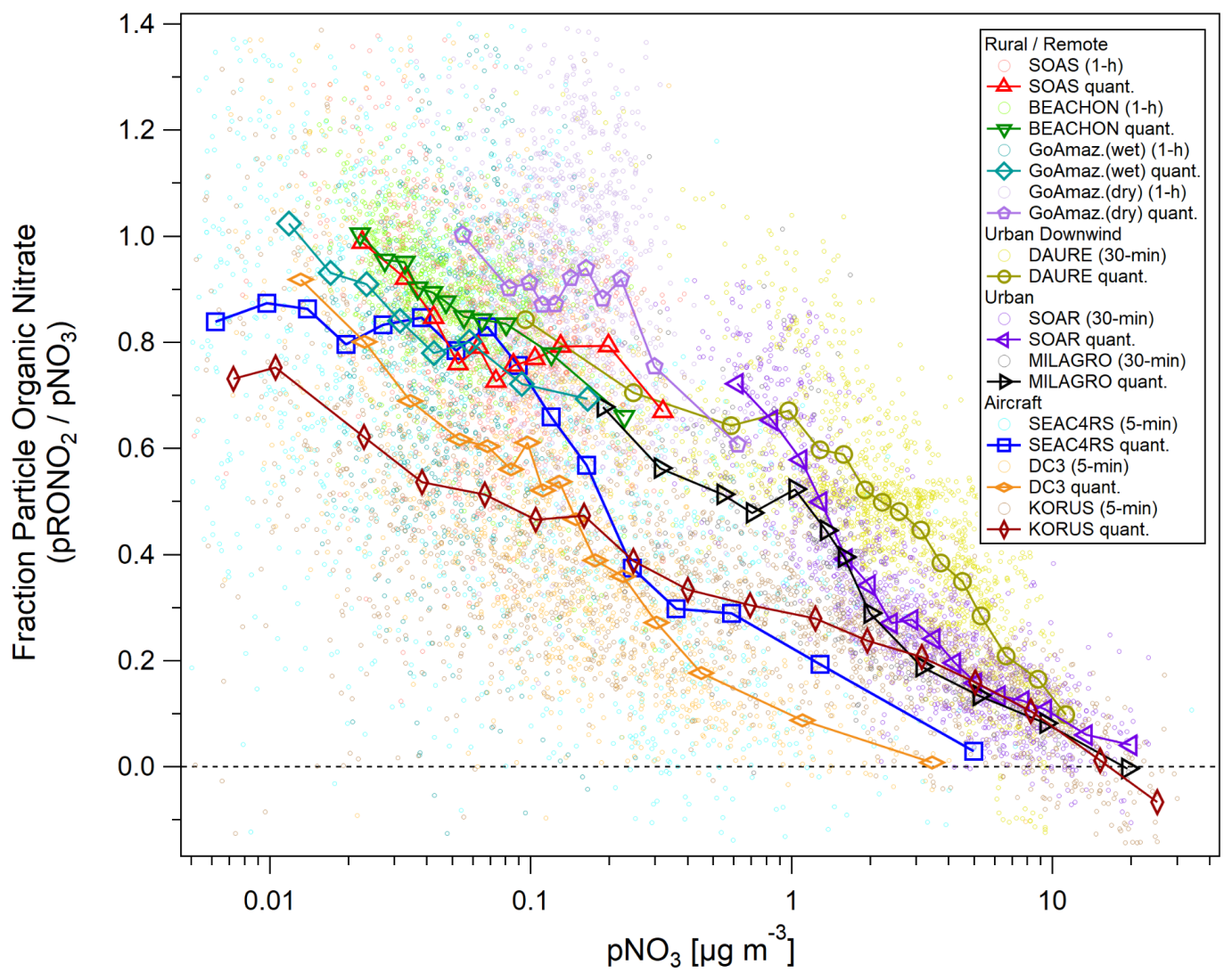

Figure 5. Fraction of total non-refractory submicron nitrate that is organic $\left(f_{\mathrm{pRONO} 2}\right)$ vs. total nitrate

845 concentration $\left(\mathrm{pNO}_{3}\right)$ for several ground and aircraft campaigns. Campaigns span: late-winter to summer across the northern hemisphere and wet/dry seasons near the equator; from ground level to the upper troposphere; and urban to remote locations. $\mathrm{NO}_{\mathrm{x}}^{+}$ion signals were first averaged and then data was conservatively screened for detection limits $(\mathrm{S} / \mathrm{N}>1-3)$ using both $\mathrm{NO}_{\mathrm{x}}{ }^{+}$ions (small circles). Quantile averages (means, $7-15$ bins) are also shown for each campaign. Additionally, for all campaigns, one 850 additional average was calculated and included with the quantile averages for the highest $1 \%$ of $\mathrm{pNO}_{3}$ in order to extend the $\mathrm{pNO}_{3}$ by a factor of $\sim 1.5-3$ (undersampled chemical regime, but with high $\mathrm{S} / \mathrm{N}$ ). The average of the lowest $1 \%$ of $\mathrm{pNO}_{3}$ for the MILAGRO campaign is also included. 


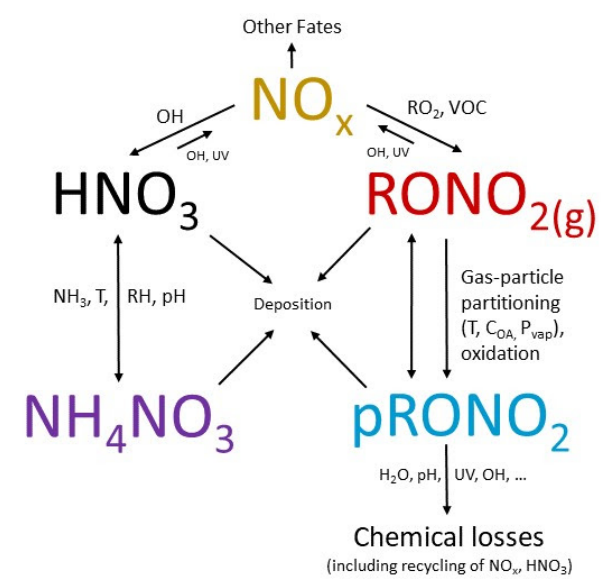

Figure 6. Schematic of key processes controlling particle-phase $\mathrm{NH}_{4} \mathrm{NO}_{3}$ and $\mathrm{pRONO}_{2}$. 


\section{References}

Aiken, A. C., Salcedo, D., Cubison, M. J., Huffman, J. A., DeCarlo, P. F., Ulbrich, I. M., Docherty, K. S., Sueper, D., Kimmel, J. R., Worsnop, D. R., Trimborn, A., Northway, M., Stone, E. A., Schauer, J. J., Volkamer, R. M., Fortner, E., de Foy, B., Wang, J., Laskin, A., Shutthanandan, V., Zheng, J., Zhang, R.,

865 Gaffney, J., Marley, N. A., Paredes-Miranda, G., Arnott, W. P., Molina, L. T., Sosa, G. and Jimenez, J. L.: Mexico City aerosol analysis during MILAGRO using high resolution aerosol mass spectrometry at the urban supersite (T0) - Part 1: Fine particle composition and organic source apportionment, Atmos. Chem. Phys., 9(17), 6633-6653, 2009.

Alfarra, M. R.: Insights into atmospheric organic aerosols using an aerosol mass spectrometer, $\mathrm{PhD}$

870 Thesis, University of Manchester Institute of Science and Technology., 2004.

Alfarra, M. R., Paulsen, D., Gysel, M., Garforth, A. a., Dommen, J., Prévôt, a. S. H., Worsnop, D. R., Baltensperger, U. and Coe, H.: A mass spectrometric study of secondary organic aerosols formed from the photooxidation of anthropogenic and biogenic precursors in a reaction chamber, Atmos. Chem. Phys., 6, 5279-5293, 2006.

875 Avery, A. M., Waring, M. S. and DeCarlo, P. F.: Seasonal variation in aerosol composition and concentration upon transport from the outdoor to indoor environment, Environ. Sci. Process. Impacts, 21, 528-547, 2019.

Ayres, B. R., Allen, H. M., Draper, D. C., Brown, S. S., Wild, R. J., Jimenez, J. L., Day, D. A., Campuzano-Jost, P., Hu, W., de Gouw, J., Koss, A., Cohen, R. C., Duffey, K. C., Romer, P., Baumann, K.,

880 Edgerton, E., Takahama, S., Thornton, J. A., Lee, B. H. H., Lopez-Hilfiker, F. D., Mohr, C., Wennberg, P. O., Nguyen, T. B., Teng, A., Goldstein, A. H., Olson, K. and Fry, J. L.: Organic nitrate aerosol formation via $\mathrm{NO}_{3}+$ biogenic volatile organic compounds in the southeastern United States, Atmos. Chem. Phys., 15(23), 13377-13392, 2015.

Bottenus, C. L. H. H., Massoli, P., Sueper, D., Canagaratna, M. R., VanderSchelden, G., Jobson, B. T. and 885 Vanreken, T. M.: Identification of amines in wintertime ambient particulate material using high resolution aerosol mass spectrometry, Atmos. Environ., 180(January), 173-183, 2018.

Boyd, C. M., Sanchez, J., Xu, L., Eugene, a. J., Nah, T., Tuet, W. Y., Guzman, M. I. and Ng, N. L.: Secondary organic aerosol formation from the $\beta$-pinene $+\mathrm{NO}_{3}$ system: effect of humidity and peroxy radical fate, Atmos. Chem. Phys., 15(13), 7497-7522, 2015.

890 Brito, J., Freney, E., Dominutti, P., Borbon, A., Haslett, S. L., Batenburg, A. M., Colomb, A., Dupuy, R., Denjean, C., Burnet, F., Bourriane, T., Deroubaix, A., Sellegri, K., Borrmann, S., Coe, H., Flamant, C., Knippertz, P. and Schwarzenboeck, A.: Assessing the role of anthropogenic and biogenic sources on $\mathrm{PM}_{1}$ over southern West Africa using aircraft measurements, Atmos. Chem. Phys., 18(2), 757-772, 2018.

Browne, E. C. and Cohen, R. C.: Effects of biogenic nitrate chemistry on the NOx lifetime in remote 895 continental regions, Atmos. Chem. Phys., 12(24), 11917-11932, 2012.

Brown, S. S., Dubé, W. P., Bahreini, R., Middlebrook, A. M., Brock, C. A., Warneke, C., De Gouw, J. A., Washenfelder, R. A., Atlas, E., Peischl, J., Ryerson, T. B., Holloway, J. S., Schwarz, J. P., Spackman, R., Trainer, M., Parrish, D. D., Fehshenfeld, F. C. and Ravishankara, A. R.: Biogenic VOC oxidation and organic aerosol formation in an urban nocturnal boundary layer: Aircraft vertical profiles in Houston, TX, 
900 Atmos. Chem. Phys., 13(22), 11317-11337, 2013.

Bruns, E. A., Perraud, V., Zelenyuk, A., Ezell, M. J., Johnson, S. N., Yu, Y., Imre, D., Finlayson-Pitts, B. J., Alexander, M. L., Bruns, A. E., Perraud, V., Zelenyuk, A., Ezell, M. J., Johnson, S. N., Yu, Y., Imre, D., Finlayson-Pitts, B. J. and Alexander, M. L.: Comparison of FTIR and particle mass spectrometry for the measurement of particulate organic nitrates, Environ. Sci. Technol., 44(3), 1056-1061, 2010.

905 Canagaratna, M. R., Jayne, J. T., Jimenez, J. L., Allan, J. D., Alfarra, M. R., Zhang, Q. Q., Onasch, T. B., Drewnick, F., Coe, H., Middlebrook, A. M., Delia, A., Williams, L. R., Trimborn, A. M., Northway, M. J., DeCarlo, P. F., Kolb, C. E., Davidovits, P. and Worsnop, D. R.: Chemical and microphysical characterization of ambient aerosols with the Aerodyne Aerosol Mass Spectrometer, Mass Spectrom. Rev., 26(2), 185-222, 2007.

910 Canonaco, F., Tobler, A., Chen, G., Sosedova, Y., Slowik, J. G., Bozzetti, C., Daellenbach, K. R., El Haddad, I., Crippa, M., Huang, R.-J., Furger, M., Baltensperger, U. and Prévôt, A. S. H.: A new method for long-term source apportionment with time-dependent factor profiles and uncertainty assessment using SoFi Pro: application to 1 year of organic aerosol data, Atmospheric Measurement Techniques, 14(2), 923-943, doi:10.5194/amt-14-923-2021, 2021.

915 Cappa, C. D., Lim, C. Y., Hagan, D. H., Coggon, M., Koss, A., Sekimoto, K., de Gouw, J., Onasch, T. B., Warneke, C. and Kroll, J. H.: Biomass-burning-derived particles from a wide variety of fuels - Part 2: Effects of photochemical aging on particle optical and chemical properties, Atmos. Chem. Phys., 20(14), 8511-8532, 2020.

Chen, W., Ye, Y., Hu, W., Zhou, H., Pan, T., Wang, Y., Song, W., Song, Q., Ye, C., Wang, C., Wang, B., 920 Huang, S., Yuan, B., Zhu, M., Lian, X., Zhang, G., Bi, X., Jiang, F., Liu, J., Canonaco, F., Prevot, A. S. H., Shao, M. and Wang, X.: Real-time characterization of aerosol compositions, sources and aging processes in Guangzhou during PRIDE-GBA 2018 campaign, J. Geophys. Res., doi:10.1029/2021jd035114, 2021.

Chen, Y., Takeuchi, M., Nah, T., Xu, L., Canagaratna, M. R., Stark, H., Baumann, K., Canonaco, F.,

925 Prévôt, A. S. H., Gregory Huey, L., Weber, R. J. and Ng, N. L.: Chemical characterization of secondary organic aerosol at a rural site in the southeastern US: insights from simultaneous high-resolution time-of-flight aerosol mass spectrometer (HR-ToF-AMS) and FIGAERO chemical ionization mass spectrometer (CIMS) measurements, Atmospheric Chemistry and Physics, 20(14), 8421-8440, doi:10.5194/acp-20-8421-2020, 2020.

930 Cubison, M. J., Ortega, A. M., Hayes, P. L., Farmer, D. K., Day, D. A., Lechner, M. J., Brune, W. H., Apel, E., Diskin, G. S., Fisher, J. A., Fuelberg, H. E., Hecobian, A., Knapp, D. J., Mikoviny, T., Riemer, D., Sachse, G. W., Sessions, W., Weber, R. J., Weinheimer, A. J., Wisthaler, A. and Jimenez, J. L.: Effects of aging on organic aerosol from open biomass burning smoke in aircraft and laboratory studies, Atmos. Chem. Phys., 11(23), 12049-12064, 2011.

935 Dai, Q., Schulze, B. C., Bi, X., Bui, A. A. T., Guo, F., Wallace, H. W., Sanchez, N. P., Flynn, J. H., Lefer, B. L., Feng, Y. and Griffin, R. J.: Seasonal differences in formation processes of oxidized organic aerosol near Houston, TX, Atmospheric Chemistry and Physics, 19(14), 9641-9661, doi:10.5194/acp-19-9641-2019, 2019.

Day, D. A., Wooldridge, P. J., Dillon, M. B., Thornton, J. A. and Cohen, R. C.: A thermal dissociation 940 laser-induced fluorescence instrument for in situ detection of $\mathrm{NO}_{2}$, peroxy nitrates, alkyl nitrates, and 
$\mathrm{HNO}_{3}$, Journal of Geophysical Research-Atmospheres, 107(D5-6), 4046-4046, 2002.

Docherty, K. S., Aiken, A. C., Huffman, J. A., Ulbrich, I. M., DeCarlo, P. F., Sueper, D., Worsnop, D. R., Snyder, D. C., Peltier, R. E., Weber, R. J., Grover, B. D., Eatough, D. J., Williams, B. J., Goldstein, A. H., Ziemann, P. J. and Jimenez, J. L.: The 2005 Study of Organic Aerosols at Riverside (SOAR-1):

945 instrumental intercomparisons and fine particle composition, Atmos. Chem. Phys., 11(23), 12387-12420, 2011.

Docherty, K. S., Lewandowski, M. and Jimenez, J. L.: Effect of Vaporizer Temperature on Ambient NonRefractory Submicron Aerosol Composition and Mass Spectra Measured by the Aerosol Mass Spectrometer Effect of Vaporizer Temperature on Ambient Non-Refractory Submicron Aerosol

950 Composition and Mass Spectra Me, Aerosol Sci. Technol., 6826(March 2017), 00-00, 2015.

Drewnick, F., Diesch, J.-M., Faber, P. and Borrmann, S.: Aerosol mass spectrometry: particle-vaporizer interactions and their consequences for the measurements, Atmos. Meas. Tech., 8(9), 3811-3830, 2015.

Farmer, D. K., Matsunaga, A., Docherty, K. S., Surratt, J. D., Seinfeld, J. H., Ziemann, P. J. and Jimenez, J. L.: Response of an aerosol mass spectrometer to organonitrates and organosulfates and implications for

955 atmospheric chemistry, Proceedings of the National Academy of Sciences, 107(15), 6670-6675, 2010.

Fisher, J. A., Jacob, D. J., Travis, K. R., Kim, P. S., Marais, E. A., Chan Miller, C., Yu, K., Zhu, L., Yantosca, R. M., Sulprizio, M. P., Mao, J., Wennberg, P. O., Crounse, J. D., Teng, A. P., Nguyen, T. B., St. Clair, J. M., Cohen, R. C., Romer, P., Nault, B. A., Wooldridge, P. J., Jimenez, J. L., Campuzano-Jost, P., Day, D. A., Hu, W., Shepson, P. B., Xiong, F., Blake, D. R., Goldstein, A. H., Misztal, P. K., Hanisco, T.

960 F., Wolfe, G. M., Ryerson, T. B., Wisthaler, A. and Mikoviny, T.: Organic nitrate chemistry and its implications for nitrogen budgets in an isoprene- and monoterpene-rich atmosphere: constraints from aircraft (SEAC ${ }^{4} \mathrm{RS}$ ) and ground-based (SOAS) observations in the Southeast US, Atmos. Chem. Phys., 16(9), 5969-5991, 2016.

Florou, K., Papanastasiou, D. K., Pikridas, M., Kaltsonoudis, C., Louvaris, E., Gkatzelis, G. I., Patoulias, 965 D., Mihalopoulos, N. and Pandis, S. N.: The contribution of wood burning and other pollution sources to wintertime organic aerosol levels in two Greek cities, Atmos. Chem. Phys., 17(4), 3145-3163, 2017.

Fröhlich, R., Cubison, M. J., Slowik, J. G., Bukowiecki, N., Prévôt, a. S. H., Baltensperger, U., Schneider, J., Kimmel, J. R., Gonin, M., Rohner, U., Worsnop, D. R. and Jayne, J. T.: The ToF-ACSM: A portable aerosol chemical speciation monitor with TOFMS detection, Atmos. Meas. Tech., 6(11), 3225-3241,

9702013.

Fry, J. L., Kiendler-Scharr, A., Rollins, A. W., Wooldridge, P. J., Brown, S. S., Fuchs, H., Dubé, W., Mensah, A., dal Maso, M., Tillmann, R., Dorn, H.-P., Brauers, T. and Cohen, R. C.: Organic nitrate and secondary organic aerosol yield from $\mathrm{NO}_{3}$ oxidation of $\beta$-pinene evaluated using a gas-phase kinetics/aerosol partitioning model, Atmos. Chem. Phys., 9(4), 1431-1449, 2009.

975 Fry, J. L., Draper, D. C., Zarzana, K. J., Campuzano-Jost, P., Day, D. A., Jimenez, J. L., Brown, S. S., Cohen, R. C., Kaser, L., Hansel, A., Cappellin, L., Karl, T., Hodzic Roux, A., Turnipseed, A., Cantrell, C., Lefer, B. L. and Grossberg, N.: Observations of gas- and aerosol-phase organic nitrates at BEACHON-RoMBAS 2011, Atmos. Chem. Phys., 13(17), 8585-8605, 2013.

Fry, J. L., Brown, S. S., Middlebrook, A. M., Edwards, P. M., Campuzano-Jost, P., Day, D. A., Jimenez, J. 980 L., Allen, H. M., Ryerson, T. B., Pollack, I., Graus, M., Warneke, C., de Gouw, J. A., Brock, C. A., 
Gilman, J., Lerner, B. M., Dubé, W. P., Liao, J. and Welti, A.: Secondary Organic Aerosol (SOA) yields from $\mathrm{NO}_{3}$ radical + isoprene based on nighttime aircraft power plant plume transects, Atmos. Chem. Phys., 18(16), 11663-11682, 2018.

Häkkinen, S. A. K., Äijälä, M., Lehtipalo, K., Junninen, H., Backman, J., Virkkula, A., Nieminen, T., 985 Vestenius, M., Hakola, H., Ehn, M., Worsnop, D. R., Kulmala, M., Petäjä, T. and Riipinen, I.: Long-term volatility measurements of submicron atmospheric aerosol in Hyytiälä, Finland, Atmos. Chem. Phys., 12(22), 10771-10786, 2012.

Hao, L. Q., Kortelainen, A., Romakkaniemi, S., Portin, H., Jaatinen, A., Leskinen, A., Komppula, M., Miettinen, P., Sueper, D., Pajunoja, A., Smith, J. N., Lehtinen, K. E. J., Worsnop, D. R., Laaksonen, A.

990 and Virtanen, A.: Atmospheric submicron aerosol composition and particulate organic nitrate formation in a boreal forestland-urban mixed region, Atmos. Chem. Phys., 14(24), 13483-13495, 2014.

Hogrefe, O., Schwab, J. J., Drewnick, F., Lala, G. G., Peters, S., Demerjian, K. L., Rhoads, K., Felton, H. D., Rattigan, O. V., Husain, L. and Dutkiewicz, V. a.: Semicontinuous PM2.5 sulfate and nitrate measurements at an urban and a rural location in New York: PMTACS-NY summer 2001 and 2002 995 campaigns, J. Air Waste Manag. Assoc., 54(9), 1040-1060, 2004.

Huang, W., Saathoff, H., Shen, X., Ramisetty, R., Leisner, T. and Mohr, C.: Chemical Characterization of Highly Functionalized Organonitrates Contributing to Night-time Organic Aerosol Mass Loadings and Particle Growth, Environ. Sci. Technol., 53(3), acs.est.8b05826-acs.est.8b05826, 2019a.

Huang, W., Saathoff, H., Shen, X., Ramisetty, R., Leisner, T. and Mohr, C.: Seasonal characteristics of 1000 organic aerosol chemical composition and volatility in Stuttgart, Germany, Atmos. Chem. Phys., 19, 11687-11700, 2019b.

Hu, W., Palm, B. B., Day, D. A., Campuzano-Jost, P., Krechmer, J. E., Peng, Z., de Sá, S. S., Martin, S. T., Alexander, M. L. L., Baumann, K., Hacker, L., Kiendler-Scharr, A., Koss, A. R., de Gouw, J. A., Goldstein, A. H., Seco, R., Sjostedt, S. J., Park, J.-H., Guenther, A. B., Kim, S., Canonaco, F., Prévôt, A.

1005 S. H., Brune, W. H. and Jimenez, J. L.: Volatility and lifetime against OH heterogeneous reaction of ambient isoprene-epoxydiols-derived secondary organic aerosol (IEPOX-SOA), Atmos. Chem. Phys., 16(18), 11563-11580, 2016.

Hu, W., Campuzano-jost, P., Day, D. A., Croteau, P., Canagaratna, R., Jayne, J. T., Worsnop, D. R., Jimenez, J. L., Hu, W., Campuzano-jost, P., Day, D. A., Croteau, P., Canagaratna, R., Jayne, J. T.,

1010 Worsnop, D. R. and Jimenez, J. L.: Evaluation of the new capture vaporizer for aerosol mass spectrometers ( AMS ) through field studies of inorganic species, Aerosol Sci. Technol., 51(6), 735-754, 2017a.

Hu, W., Campuzano-Jost, P., Day, D. A., Croteau, P., Canagaratna, M. R., Jayne, J. T., Worsnop, D. R. and Jimenez, J. L.: Evaluation of the new capture vapourizer for aerosol mass spectrometers (AMS) through 1015 laboratory studies of inorganic species, Atmos. Meas. Tech., 10(6), 2897-2921, $2017 \mathrm{~b}$.

Jayne, J. T., Leard, D. C., Zhang, X. F., Davidovits, P., Smith, K. A., Kolb, C. E. and Worsnop, D. R.: Development of an aerosol mass spectrometer for size and composition analysis of submicron particles, Aerosol Sci. Technol., 33(1-2), 49-70, 2000.

Jayne, J. T., Croteau, P. L., Lambe, A. T., Xu, W., Onasch, T. B., Wolff, L. and Canagaratna, M. R.: 1020 Investigation of $f 44$ variability in AMS and ACSM instruments, in 16th Aerosol Mass Spectrometer 
Users' Meeting, Milan, Italy. [online] Available from:

http://cires1.colorado.edu/jimenez-group/UsrMtgs/UsersMtg16/Jayne_f44Intro.pdf (Accessed 11 August 2021), 2015.

Jimenez, J. L., Jayne, J. T., Shi, Q., Kolb, C. E., Worsnop, D. R., Yourshaw, I., Seinfeld, J. H., Flagan, R. 1025 C., Zhang, X. F., Smith, K. A., Morris, J. W. and Davidovits, P.: Ambient aerosol sampling using the Aerodyne Aerosol Mass Spectrometer, J. Geophys. Res., 108(D7), 8425-8425, 2003.

Jimenez, J. L., Canagaratna, M. R., Drewnick, F., Allan, J. D., Alfarra, M. R., Middlebrook, A. M., Slowik, J. G., Zhang, Q., Coe, H., Jayne, J. T. and Worsnop, D. R.: Comment on "The effects of molecular weight and thermal decomposition on the sensitivity of a thermal desorption aerosol mass 1030 spectrometer," Aerosol Sci. Technol., 50(9), i-xv, 2016.

Kiendler-Scharr, A., Mensah, A. A., Friese, E., Topping, D., Nemitz, E., Prevot, A. S. H., Äijälä, M., Allan, J., Canonaco, F., Canagaratna, M., Carbone, S., Crippa, M., Dall Osto, M., Day, D. A., DeCarlo, P., Di Marco, C. F., Elbern, H., Eriksson, A., Freney, E., Hao, L., Herrmann, H., Hildebrandt, L., Hillamo, R., Jimenez, J. L., Laaksonen, A., McFiggans, G., Mohr, C., O’Dowd, C., Otjes, R., Ovadnevaite, J.,

1035 Pandis, S. N., Poulain, L., Schlag, P., Sellegri, K., Swietlicki, E., Tiitta, P., Vermeulen, A., Wahner, A., Worsnop, D. and Wu, H.-C.: Organic nitrates from night-time chemistry are ubiquitous in the European submicron aerosol, Geophys. Res. Lett., 43(14), 7735-7744, 2016.

Kim, H., Zhang, Q. and Heo, J.: Influence of intense secondary aerosol formation and long-range transport on aerosol chemistry and properties in the Seoul Metropolitan Area during spring time: Results 1040 from KORUS-AQ, Atmos. Chem. Phys., 18(10), 7149-7168, 2018.

Kortelainen, A., Hao, L., Tiitta, P., Jaatinen, A., Miettinen, P., Kulmala, M., Smith, J. N., Laaksonen, A., Worsnop, D. R. and Virtanen, A.: Sources of particulate organic nitrates in the boreal forest in Finland, Boreal Environ. Res., 22, 13-26, 2017.

Kostenidou, E., Florou, K., Kaltsonoudis, C., Tsiflikiotou, M., Vratolis, S., Eleftheriadis, K. and Pandis, 1045 S. N.: Sources and chemical characterization of organic aerosol during the summer in the eastern Mediterranean, Atmos. Chem. Phys., 15(19), 11355-11371, 2015.

Lee, A. K. Y., Adam, M. G., Liggio, J., Li, S.-M., Li, K., Willis, M. D., Abbatt, J. P. D., Tokarek, T. W., Odame-Ankrah, C. A., Osthoff, H. D. and Others: A large contribution of anthropogenic organo-nitrates to secondary organic aerosol in the Alberta oil sands, Atmos. Chem. Phys., 19(19), 12209-12219, 2019.

1050 Lee, B. H., Mohr, C., Lopez-Hilfiker, F. D., Lutz, A., Hallquist, M., Lee, L., Romer, P., Cohen, R. C., Iyer, S., Kurtén, T., Hu, W., Day, D. A., Campuzano-Jost, P., Jimenez, J. L., Xu, L., Ng, N. L., Guo, H., Weber, R. J., Wild, R. J., Brown, S. S., Koss, A., de Gouw, J., Olson, K., Goldstein, A. H., Seco, R., Kim, S., McAvey, K., Shepson, P. B., Starn, T., Baumann, K., Edgerton, E. S., Liu, J., Shilling, J. E., Miller, D. O., Brune, W., Schobesberger, S., D’Ambro, E. L. and Thornton, J. A.: Highly functionalized organic nitrates 1055 in the southeast U.S.: Contribution to secondary organic aerosol and reactive nitrogen budgets, Proc. Natl. Acad. Sci., 113(6), 1516-1521, 2016.

Lopez-Hilfiker, F. D., Mohr, C., Ehn, M., Rubach, F., Kleist, E., Wildt, J., Mentel, T. F., Lutz, A., Hallquist, M., Worsnop, D. and Thornton, J. A.: A novel method for online analysis of gas and particle composition: description and evaluation of a Filter Inlet for Gases and AEROsols (FIGAERO), Atmos.

1060 Meas. Tech., 7(4), 983-1001, 2014. 
Maria, S. F., Russell, L. M., Turpin, B. J. and Porcja, R. J.: FTIR measurements of functional groups and organic mass in aerosol samples over the Caribbean, Atmos. Environ., 36(33), 5185-5196, 2002.

McClure, C. D., Lim, C. Y., Hagan, D. H., Kroll, J. H. and Cappa, C. D.: Biomass-burning-derived particles from a wide variety of fuels - Part 1: Properties of primary particles, Atmos. Chem. Phys., 20(3), 1065 1531-1547, 2020.

Minguillon', M. C., Perron, N., Querol, X., Szidat, S., Fahrni, S. M., Alastuey, A., Jimenez, J. L., Mohr, C., Ortega, A. M., Day, D. A., Lanz, V. A., Wacker, L., Reche, C., Cusack, M., Amato, F., Kiss, G., Hoffer, A., Decesari, S., Moretti, F., Hillamo, R., Teinila, K., Seco, R., Penuelas, J., Metzger, A., Schallhart, S., Muller, M., Hansel, A., Burkhart, J. F., Baltensperger, U. and Prevot, A. S. H.: Fossil 1070 versus contemporary sources of fine elemental and organic carbonaceous particulate matter during the DAURE campaign in Northeast Spain, Atmos. Chem. Phys., 11(23), 12067-12084, 2011.

Nault, B. A., Garland, C., Wooldridge, P. J., Brune, W. H., Campuzano-Jost, P., Crounse, J. D., Day, D. A., Dibb, J., Hall, S. R., Huey, L. G., Jimenez, J. L., Liu, X., Mao, J., Mikoviny, T., Peischl, J., Pollack, I. B., Ren, X., Ryerson, T. B., Scheuer, E., Ullmann, K., Wennberg, P. O., Wisthaler, A., Zhang, L. and

1075 Cohen, R. C.: Observational Constraints on the Oxidation of $\mathrm{NO}_{\mathrm{x}}$ in the Upper Troposphere, J. Phys. Chem. A, 120(9), doi:10.1021/acs.jpca.5b07824, 2016.

Nault, B. A., Campuzano-Jost, P., Day, D. A., Schroder, J. C., Anderson, B., Beyersdorf, A. J., Blake, D. R., Brune, W. H., Choi, Y., Corr, C. A., de Gouw, J. A., Dibb, J., DiGangi, J. P., Diskin, G. S., Fried, A., Huey, L. G., Kim, M. J., Knote, C. J., Lamb, K. D., Lee, T., Park, T., Pusede, S. E., Scheuer, E., Thornhill,

1080 K. L., Woo, J.-H. and Jimenez, J. L.: Secondary organic aerosol production from local emissions dominates the organic aerosol budget over Seoul, South Korea, during KORUS-AQ, Atmos. Chem. Phys., 18(24), 17769-17800, 2018.

Nault, B. A., Campuzano-Jost, P., Day, D. A., Jo, D. S., Schroder, J. C., Allen, H. M., Bahreini, R., Bian, H., Blake, D. R., Chin, M., Clegg, S. L., Colarco, P., Crounse, J., Cubison, M. J., DeCarlo, P. F., Dibb, J., 1085 Diskin, G. S., Hodzic, A., Hu, W., Katich, J. M., Kim, M. J., Kodros, J., Kupc, A., Lopez-Hilfiker, F. D., Marais, E. A., Middlebrook, A., Neuman, J. A., Nowak, J. B., Palm, B. B., Paulot, F., Pierce, J., Schill, G. P., Scheuer, E., Thornton, J. A., Tsigaridis, P. R., Wennberg, P. O., Williamson, C. J. and Jimenez, J. L.: Models underestimate the increase of acidity with remoteness biasing radiative impact calculations, Communications Earth \& Environment, 2(93), doi:10.1038/s43247-021-00164-0, 2021.

1090 Ng, N. L., Herndon, S. C., Trimborn, A., Canagaratna, M. R., Croteau, P. L., Onasch, T. B., Sueper, D., Worsnop, D. R., Zhang, Q., Sun, Y. L. and Jayne, J. T.: An Aerosol Chemical Speciation Monitor (ACSM) for Routine Monitoring of the Composition and Mass Concentrations of Ambient Aerosol, Aerosol Sci. Technol., 45(7), 780-794, 2011.

Ng, N. L., Brown, S. S., Archibald, A. T., Atlas, Elliot, Cohen, R. C., Crowley, J. N., Day, D. A., 1095 Donahue, N. M., Fry, J. L., Fuchs, H., Griffin, R. J., Guzman, M. I., Herrmann, H., Hodzic, A., Iinuma, Y., Kiendler-Scharr, A., Lee, B. H., Luecken, D. J., Mao, J., McLaren, R., Mutzel, A., Osthoff, H. D., Ouyang, B., Picquet-Varrault, B., Platt, U., Pye, H. O. T., Rudich, Y., Schwantes, R. H., Shiraiwa, M., Stutz, J., Thornton, J. A., Tilgner, A., Williams, B. J. and Zaveri, R. A.: Nitrate radicals and biogenic volatile organic compounds: oxidation, mechanisms, and organic aerosol, Atmos. Chem. Phys., 17(3),

1100 2103-2162, 2017.

Pagonis, D., Campuzano-Jost, P., Guo, H., Day, D. A., Schueneman, M. K., Brown, W. L., Nault, B. A., 
Stark, H., Siemens, K., Laskin, A., Piel, F., Tomsche, L., Wisthaler, A., Coggon, M. M., Gkatzelis, G. I., Halliday, H. S., Krechmer, J. E., Moore, R. H., Thomson, D. S., Warneke, C., Wiggins, E. B. and Jimenez, J. L.: Airborne extractive electrospray mass spectrometry measurements of the chemical composition of 1105 organic aerosol, Atmos. Chem. Phys., 14(2), 1545-1559, 2021.

Palm, B. B., Campuzano-Jost, P., Day, D. A., Ortega, A. M., Fry, J. L., Brown, S. S., Zarzana, K. J., Dube, W., Wagner, N. L., Draper, D. C., Kaser, L., Jud, W., Karl, T., Hansel, A., Gutiérrez-Montes, C. and Jimenez, J. L.: Secondary organic aerosol formation from in situ $\mathrm{OH}, \mathrm{O}_{3}$, and $\mathrm{NO}_{3}$ oxidation of ambient forest air in an oxidation flow reactor, Atmos. Chem. Phys., 17(8), 5331-5354, 2017.

1110 Perring, A. E., Bertram, T. H., Wooldridge, P. J., Fried, A., Heikes, B. G., Dibb, J., Crounse, J. D., Wennberg, P. O., Blake, N. J., Blake, D. R., Brune, W. H., Singh, H. B. and Cohen, R. C.: Airborne observations of total $\mathrm{RONO}_{2}$ : new constraints on the yield and lifetime of isoprene nitrates, Atmos. Chem. Phys., 9(4), 1451-1463, 2009.

Pullinen, I., Schmitt, S., Kang, S., Sarrafzadeh, M., Schlag, P., Andres, S., Kleist, E., Mentel, T. F.,

1115 Rohrer, F., Springer, M., Tillmann, R., Wildt, J., Wu, C., Zhao, D., Wahner, A. and Kiendler-Scharr, A.: Impact of $\mathrm{NO}_{x}$ on secondary organic aerosol (SOA) formation from $\alpha$-pinene and $\beta$-pinene photooxidation: the role of highly oxygenated organic nitrates, Atmos. Chem. Phys., 20(17), 10125-10147, 2020.

Pye, H. O. T., Luecken, D. J., Xu, L., Boyd, C. M., Ng, N. L., Baker, K. R., Ayres, B. R., Bash, J. O.,

1120 Baumann, K., Carter, W. P. L., Edgerton, E. S., Fry, J. L., Hutzell, W. T., Schwede, D. B. and Shepson, P. B.: Modeling the current and future roles of particulate organic nitrates in the southeastern United States, Environ. Sci. Technol., acs.est.5b03738-acs.est.5b03738, 2015.

Reyes-Villegas, E., Priestley, M., Ting, Y.-C., Haslett, S., Bannan, T., Le Breton, M., Williams, P. I., Bacak, A., Flynn, M. J., Coe, H., Percival, C., Allan, J. D., Breton, M. L., Attribution, Creative

1125 Commons, Reyes-Villegas, E., Reyes-Villegas, E. and By, C. C.: Simultaneous aerosol mass spectrometry and chemical ionisation mass spectrometry measurements during a biomass burning event in the UK : insights into nitrate chemistry, Atmos. Chem. Phys., 18(6), 4093-4111, 2018.

Rollins, A. W., Kiendler-Scharr, A., Fry, J. L., Brauers, T., Brown, S. S., Dorn, H.-P., Dubé, W. P., Fuchs, H., Mensah, A., Mentel, T. F., Rohrer, F., Tilmann, R., Wegener, R., Wooldridge, P. J. and Cohen, R. C.:

1130 Isoprene oxidation by nitrate radical: alkyl nitrate and secondary organic aerosol yields, Atmos. Chem. Phys., 9, 6685-6703, 2009.

Rollins, A. W., Pusede, S., Wooldridge, P., Min, K.-E., Gentner, D. R., Goldstein, A. H., Liu, S., Day, D. A., Russell, L. M., Rubitschun, C. L., Surratt, J. D. and Cohen, R. C.: Gas/particle partitioning of total alkyl nitrates observed with TD-LIF in Bakersfield, J. Geophys. Res. D: Atmos., 118(12), 6651-6662,

11352013.

Romer, P. S.: Chemical removal of nitrogen oxides from the atmosphere: Impacts on air quality and effects of temperature, $\mathrm{PhD}$ Thesis, University of California, Berkeley. [online] Available from: http://digitalassets.lib.berkeley.edu/etd/ucb/text/Romer_berkeley_0028E_18182.pdf (Accessed 11 August, 2021), 2018.

1140 Saleh, R., Robinson, E. S., Ahern, A. T., Donahue, N. M., Saleh, R., Robinson, E. S., Ahern, A. T. and Donahue, N. M.: Evaporation rate of particles in the vaporizer of the Aerodyne aerosol mass 
spectrometer, Aerosol Sci. Technol., 51(4), 501-508, 2017.

de Sá, S. S., Palm, B. B., Campuzano-Jost, P., Day, D. A., Hu, W., Isaacman-VanWertz, G., Yee, L. D., Brito, J., Carbone, S., Ribeiro, I. O., Cirino, G. G., Liu, Y. J., Thalman, R., Sedlacek, A., Funk, A., 1145 Schumacher, C., Shilling, J. E., Schneider, J., Artaxo, P., Goldstein, A. H., Souza, R. A. F., Wang, J., McKinney, K. A., Barbosa, H., Alexander, M. L., Jimenez, J. L. and Martin, S. T.: Urban influence on the concentration and composition of submicron particulate matter in central Amazonia, Atmos. Chem. Phys., 18(16), 12185-12206, 2018.

de Sá, S. S., Rizzo, L. V., Palm, B. B., Campuzano-Jost, P., Day, D. A., Yee, L. D., Wernis, R.,

1150 Isaacman-VanWertz, G., Brito, J., Carbone, S., Liu, Y. J., Sedlacek, A., Springston, S., Goldstein, A. H., Barbosa, H. M. J., Alexander, M. L., Artaxo, P., Jimenez, J. L. and Martin, S. T.: Contributions of biomass-burning, urban, and biogenic emissions to the concentrations and light-absorbing properties of particulate matter in central Amazonia during the dry season, Atmos. Chem. Phys., 19, 7973-8001, 2019.

Schneider, J., Mertes, S., Van Pinxteren, D., Herrmann, H. and Borrmann, S.: Uptake of nitric acid, 1155 ammonia, and organics in orographic clouds: Mass spectrometric analyses of droplet residual and interstitial aerosol particles, Atmos. Chem. Phys., 17(2), 1571-1593, 2017.

Schroder, J. C., Campuzano-Jost, P., Day, D. A., Shah, V., Larson, K., Sommers, J. M., Sullivan, A. P., Campos, T., Reeves, J. M., Hills, A., Hornbrook, R. S., Blake, N. J., Scheuer, E., Guo, H., Fibiger, D. L., McDuffie, E. E., Hayes, P. L., Weber, R. J., Dibb, J. E., Apel, E. C., Jaeglé, L., Brown, S. S., Thornton, J.

1160 A. and Jimenez, J. L.: Sources and Secondary Production of Organic Aerosols in the Northeastern United States during WINTER, J. Geophys. Res. D: Atmos., 123(14), 7771-7796, 2018.

Schueneman, M. K., Nault, B. A., Campuzano-Jost, P., Jo, D. S., Day, D. A., Schroder, J. C., Palm, B. B., Hodzic, A., Dibb, J. E. and Jimenez, J. L.: Aerosol pH indicator and organosulfate detectability from aerosol mass spectrometry measurements, Atmos. Meas. Tech., 14(3), 2237-2260, 2021.

1165 Schulz, C., Schneider, J., Holanda, B. A., Appel, O., Costa, A., de Sá, S. S., Dreiling, V., Fütterer, D., Jurkat-Witschas, T., Klimach, T., Knote, C., Krämer, M., Martin, S. T., Mertes, S., Pöhlker, M. L., Sauer, D., Voigt, C., Walser, A., Weinzierl, B., Ziereis, H., Zöger, M., Andreae, M. O., Artaxo, P., Machado, L. A. T., Pöschl, U., Wendisch, M. and Borrmann, S.: Aircraft-based observations of isoprene-epoxydiol-derived secondary organic aerosol (IEPOX-SOA) in the tropical upper troposphere 1170 over the Amazon region, Atmos. Chem. Phys., 18(20), 14979-15001, 2018.

Setyan, A., Zhang, Q., Merkel, M., Knighton, W. B., Sun, Y., Song, C., Shilling, J. E., Onasch, T. B., Herndon, S. C., Worsnop, D. R., Fast, J. D., Zaveri, R. A., Berg, L. K., Wiedensohler, A., Flowers, B. A., Dubey, M. K. and Subramanian, R.: Characterization of submicron particles influenced by mixed biogenic and anthropogenic emissions using high-resolution aerosol mass spectrometry: results from

1175 CARES, Atmos. Chem. Phys., 12(17), 8131-8156, 2012.

Sun, Y. L., Zhang, Q., Schwab, J. J., Yang, T., Ng, N. L. and Demerjian, K. L.: Factor analysis of combined organic and inorganic aerosol mass spectra from high resolution aerosol mass spectrometer measurements, Atmos. Chem. Phys., 12(18), 8537-8551, 2012.

Surratt, J. D., Murphy, S. M., Kroll, J. H., Ng, N. L., Hildebrandt, L., Sorooshian, A., Szmigielski, R., 1180 Vermeylen, R., Maenhaut, W., Claeys, M., Flagan, R. C. and Seinfeld, J. H.: Chemical composition of secondary organic aerosol formed from the photooxidation of isoprene, J. Phys. Chem. A, 110(31), 
Takeuchi, M. and Ng, N. L.: Chemical composition and hydrolysis of organic nitrate aerosol formed from hydroxyl and nitrate radical oxidation of $\alpha$-pinene and $\beta$-pinene, Atmos. Chem. Phys., 19(19), 1185 12749-12766, 2019.

Tiitta, P., Leskinen, A., Hao, L., Yli-Pirilä, P., Kortelainen, M., Grigonyte, J., Tissari, J., Lamberg, H., Hartikainen, A., Kuuspalo, K., Kortelainen, A.-M. M., Virtanen, A., Lehtinen, K. E. J., Komppula, M., Pieber, S., Prévôt, A. S. H., Onasch, T. B., Worsnop, D. R., Czech, H., Zimmermann, R., Jokiniemi, J. and Sippula, O.: Transformation of logwood combustion emissions in a smog chamber: formation of

1190 secondary organic aerosol and changes in the primary organic aerosol upon daytime and nighttime aging, Atmos. Chem. Phys., 16(20), 13251-13269, 2016.

Xu, L., Suresh, S., Guo, H., Weber, R. J. and Ng, N. L.: Aerosol characterization over the southeastern United States using high-resolution aerosol mass spectrometry: spatial and seasonal variation of aerosol composition and sources with a focus on organic nitrates, Atmos. Chem. Phys., 15(13), 7307-7336,

$11952015 a$.

Xu, L., Guo, H., Boyd, C. M., Klein, M., Bougiatioti, A., Cerully, K. M., Hite, J. R., Isaacman-VanWertz, G., Kreisberg, N. M., Knote, C., Olson, K., Koss, A., Goldstein, A. H., Hering, S. V., de Gouw, J., Baumann, K., Lee, S.-H., Nenes, A., Weber, R. J. and Ng, N. L.: Effects of anthropogenic emissions on aerosol formation from isoprene and monoterpenes in the southeastern United States, Proceedings of the

1200 National Academy of Sciences, 112(1), 37-42, $2015 \mathrm{~b}$.

Xu, L., Williams, L. R., Young, D. E., Allan, J. D., Coe, H., Massoli, P., Fortner, E., Chhabra, P., Herndon, S., Brooks, W. A., Jayne, J. T., Worsnop, D. R., Aiken, A. C., Liu, S., Gorkowski, K., Dubey, M. K., Fleming, Z. L., Visser, S., Prévôt, A. S. H. and Ng, N. L.: Wintertime aerosol chemical composition, volatility, and spatial variability in the greater London area, Atmos. Chem. Phys., 16(2), 1205 1139-1160, 2016.

Xu, W., Takeuchi, M., Chen, C., Qiu, Y., Xie, C., Xu, W., Ma, N., Worsnop, D. R., Ng, N. L. and Sun, Y.: Estimation of particulate organic nitrates from thermodenuder-aerosol mass spectrometer measurements in the North China Plain, Atmospheric Measurement Techniques, 14(5), 3693-3705, doi:10.5194/amt-14-3693-2021, 2021.

1210 Yu, K., Zhu, Q., Du, K. and Huang, X.-F.: Characterization of nighttime formation of particulate organic nitrates based on high-resolution aerosol mass spectrometry in an urban atmosphere in China, Atmos. Chem. Phys., 19(7), 5235-5249, 2019.

Zare, A., Romer, P. S., Nguyen, T., Keutsch, F. N., Skog, K. and Cohen, R. C.: A comprehensive organic nitrate chemistry: insights into the lifetime of atmospheric organic nitrates, Atmos. Chem. Phys., 18(20), 1215 15419-15436, 2018.

Zaveri, R. A., Berkowitz, C. M., Brechtel, F. J., Gilles, M. K., Hubbe, J. M., Jayne, J. T., Kleinman, L. I., Laskin, A., Madronich, S., Onasch, T. B., Pekour, M. S., Springston, S. R., Thornton, J. A., Tivanski, A. V. and Worsnop, D. R.: Nighttime chemical evolution of aerosol and trace gases in a power plant plume: Implications for secondary organic nitrate and organosulfate aerosol formation, $\mathrm{NO}_{3}$ radical chemistry, 1220 and $\mathrm{N}_{2} \mathrm{O}_{5}$ heterogeneous hydrolysis, J. Geophys. Res. D: Atmos., 115(12), 1-22, 2010.

Zhang, J. K., Cheng, M. T., Ji, D. S., Liu, Z. R., Hu, B., Sun, Y. and Wang, Y. S.: Characterization of 
submicron particles during biomass burning and coal combustion periods in Beijing, China, Sci. Total Environ., 562, 812-821, 2016.

Zhang, Q. and Jimenez, J. L.: Aerosol Mass Spectrometry (AMS) Global Database, [online] Available 1225 from: https://sites.google.com/site/amsglobaldatabase/urban-down-wind/montseny-spain (Accessed 11 August, 2021), 2021.

Zhang, Q., Stanier, C. O., Canagaratna, M. R., Jayne, J. T., Worsnop, D. R., Pandis, S. N. and Jimenez, J. L.: Insights into the chemistry of new particle formation and growth events in Pittsburgh based on aerosol mass spectrometry, Environ. Sci. Technol., 38(18), 4797-4809, 2004.

1230 Zhao, D., Schmitt, S. H., Wang, M., Acir, I.-H., Tillmann, R., Tan, Z., Novelli, A., Fuchs, H., Pullinen, I., Wegener, R. and Others: Effects of NOx and $\mathrm{SO} 2$ on the secondary organic aerosol formation from photooxidation of $\alpha$-pinene and limonene, Atmos. Chem. Phys., 18(3), 1611-1628, 2018.

Zhou, S., Collier, S., Xu, J., Mei, F., Wang, J., Lee, Y.-N., Sedlacek, A. J., Springston, S. R., Sun, Y. and Zhang, Q.: Influences of upwind emission sources and atmospheric processing on aerosol chemistry and 1235 properties at a rural location in the Northeastern U.S, J. Geophys. Res. D: Atmos., 121(10), 6049-6065, 2016.

Zhu, Q., He, L.-Y., Huang, X.-F., Cao, L.-M., Gong, Z.-H., Wang, C., Zhuang, X. and Hu, M.:

Atmospheric aerosol compositions and sources at two national background sites in northern and southern China, Atmos. Chem. Phys., 16(15), 10283-10297, 2016.

1240 Zhu, Q., Cao, L.-M., Tang, M.-X., Huang, X.-F., Saikawa, E. and He, L.-Y.: Characterization of Organic Aerosol at a Rural Site in the North China Plain Region: Sources, Volatility and Organonitrates, Adv. Atmos. Sci., 38(7), 1115-1127, 2021. 